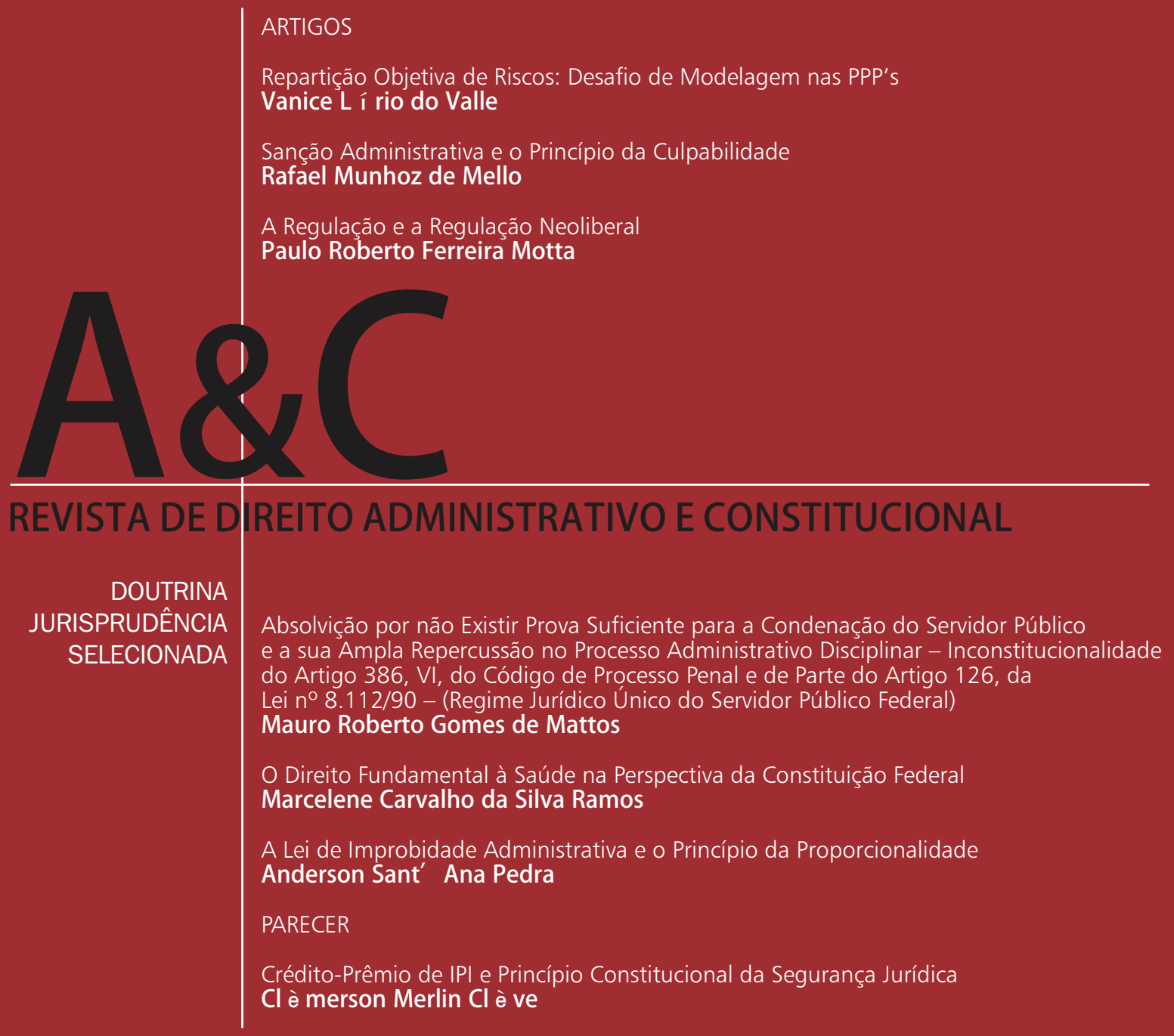

Repartição Objetiva de Riscos: Desafio de Modelagem nas PPP's Vanice $L$ í rio do Valle

Sanção Administrativa e o Princípio da Culpabilidade Rafael Munhoz de Mello

A Regulacão e a Regulação Neolibera

Paulo Roberto Ferreira Motta

do Artigo 386, VI, do Código de Processo Penal e de Parte do Artigo 126, da

8.112/90 - (Regime Juridico Unico do Servidor Público Federal)

Direito Fundamental à Saúde na Perspectiva da Constituição Federa

Marcelene Carvalho da Silva Ramos

A Lei de Improbidade Administrativa e o Princípio da Proporcionalidade

'Ana Pedra

Crédito-Prêmio de IPI e Princípio Constitucional da Segurança Jurídica

$\mathrm{Cl}$ è merson Merlin $\mathrm{Cl}$ è ve 


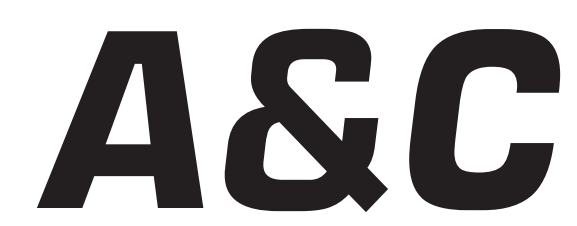

Revista de Direito Administrativo \& Constitucional

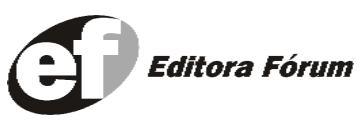

A\&C R. de Dir. Administrativo e Constitucional, Belo Horizonte, ano 5, n. 22, p. 1-253, out./dez. 2005 


\section{A\&C REVISTA DE DIREITO ADMINISTRATIVO E CONSTITUCIONAL}

\section{IPDA}

Instituto Paranaense

de Direito Administrativo

Direção Geral

Romeu Felipe Bacellar Filho

Direção Editorial

Paulo Roberto Ferreira Motta

Direção Executiva

Emerson Gabardo

Conselho de Redação

Edgar Chiuratto Guimarães

Adriana da Costa Ricardo Schier

Célio Heitor Guimarães

Conselho Editorial

Adilson Abreu Dallari

Alice Gonzáles Borges

Carlos Ari Sundfeld

Carlos Ayres Britto

Carlos Delpiazzo

Cármen Lúcia Antunes Rocha

Celso Antônio Bandeira de Mello

Clèmerson Merlin Clève

Clóvis Beznos

Enrique Silva Cimma

Eros Roberto Grau

Fabrício Motta

Guilhermo Andrés Muñoz (in memoriam)

Jaime Rodríguez-Arana Muñoz

Jorge Luís Salomoni
José Carlos Abraão
José Eduardo Martins Cardoso

José Luís Said

José Mario Serrate Paz

Juan Pablo Cajarville Peruffo

Juarez Freitas

Julio Rodolfo Comadira

Luís Enrique Chase Plate

Lúcia Valle Figueiredo

Manoel de Oliveira Franco Sobrinho

(in memoriam)

Marçal Justen Filho

Marcelo Figueiredo

Márcio Cammarosano

Maria Cristina Cesar de Oliveira
Nelson Figueiredo

Odilon Borges Junior

Pascual Caiella

Paulo Eduardo Garrido Modesto

Paulo Henrique Blasi

Paulo Neves de Carvalho (in memoriam)

Paulo Ricardo Schier

Pedro Paulo de Almeida Dutra

Regina Maria Macedo Nery Ferrari

Rogério Gesta Leal

Rolando Pantoja Bauzá

Sérgio Ferraz

Valmir Pontes Filho

Yara Stropa

Weida Zancaner

\footnotetext{
A246 A\&C Revista de Direito Administrativo e Constitucional. ano 3, n. 11, jan./mar. 2003. Belo Horizonte: Fórum, 2003.

Trimestral

ano 1, n.1, 1999 até ano 2, n.10, 2002 publicada pela Editora Juruá em Curitiba

ISSN: 1516-3210

1. Direito Administrativo. 2. Direito Constitucional. I. Fórum.
}

CDD: 342 CDU: 33.342

(c) Editora Fórum Ltda. 2005

Todos os direitos reservados. É proibida a reprodução total ou parcial, de qualquer forma ou por qualquer meio eletrônico ou mecânico, inclusive através de processos xerográficos, de fotocópias ou de gravação, sem permissão por escrito do possuidor dos direitos de cópias (Lei $n^{\circ}$ 9.610, de 19.02.1998).

Editora Fórum Ltda

Av. Afonso Pena, 2770 - 15\%16ªndar - Funcionários

CEP 30130-007 - Belo Horizonte/MG - Brasil

Tel.: 08007043737

Internet: www.editoraforum.com.br

e-mail: editoraforum@editoraforum.com.br
Editor responsável: Luís Cláudio Rodrigues Ferreira Projeto gráfico e diagramação: Luis Alberto Pimenta Revisora: Olga M. A. Sousa

Pesquisa jurídica: Fátima Ribeiro - OAB/MG 74868

Bibliotecária: Nilcéia Lage de Medeiros

CRB 1545/MG 6a região

Os conceitos e opiniões expressas nos trabalhos assinados são de responsabilidade exclusiva de seus autores.

Impressa no Brasil / Printed in Brazil

Distribuída em todo Território Nacional 


\title{
Crédito-Prêmio de IPI e Princípio Constitucional da Segurança Jurídica ${ }^{1}$
}

\author{
Clèmerson Merlin Clève \\ Professor Doutor em Direito Constitucional. Titular da UFPr e da UniBrasil. Professor nos Cursos \\ de Mestrado e Doutorado
}

\begin{abstract}
Sumário: I Contextualização - II A consulta - III Premissas - IV Princípio constitucional da segurança jurídica - IV.1 Estado democrático de direito e fundamentação do princípio da segurança jurídica - IV.2 Aspectos normativos do princípio da segurança jurídica - IV.3 Dimensão objetiva da segurança jurídica - IV.3.1 Previsibilidade - IV.3.2 Mecanismos constitucionais de tutela da segurança jurídica na concreção do direito - IV.4 Dimensão subjetiva da segurança jurídica - IV.4.1 Confiança legítima - IV.4.2 Proteção da boa-fé - V Jurisprudência e segurança jurídica - VI Direito vivo e papel do judiciário VII Precedentes no Direito brasileiro - VIII Decisões judiciais sobre o créditoprêmio de IPI - IX Eventual guinada jurisprudencial: limites eficaciais - IX.1 Considerações iniciais - IX.2 Limites eficaciais e Direito brasileiro - IX.3 Proteção da confiança legítima, prévio conhecimento e efeito anúncio - X Sínteses conclusivas - XI Resposta aos quesitos
\end{abstract}

Assunto: Crédito-prêmio de IPI e princípio constitucional da segurança jurídica.

Ementa: Crédito-prêmio de IPI. Segurança Jurídica: dimensões objetiva e subjetiva. Eventual modificação da jurisprudência do Superior Tribunal de Justiça. Efeitos prospectivos. Modelação dos efeitos. Proteção de confiança legítima e efeito anúncio. Cotejo com mudança legislativa. Período de transição.

\section{Contextualização}

01. O crédito-prêmio do Imposto sobre Produtos Industrializados - IPI foi instituído pela União Federal, por meio do Decreto-lei no 461/69, como espécie de incentivo às exportações de produtos nacionais e como mecanismo de ressarcimento, sendo a importância respectiva utilizada, principalmente, a título de compensação, no pagamento de tributos federais.

02. Na seqüência, sobrevém o Decreto-lei no 1248/72 que, ampliando o mencionado incentivo, previu que não somente as vendas, mas também as operações de aquisição de produtos no mercado interno cuja destinação

\footnotetext{
1 Agradeço às advogadas Melina Breckenfeld Reck e Alessandra Ferreira Martins, integrantes do escritório Clèmerson Merlin Clève Advogados Associados, pelo inestimável auxílio na elaboração deste parecer.
} 
fosse a exportação usufruiriam do benefício.

03. Todavia, mercê de contingências políticas e de razões fiscais, foram editados no ano de 1979: o Decreto-lei no 1658, em 24 de janeiro, que determinou a extinção gradual e paulatina do incentivo e fixou 30 de junho de 1983 como a data de sua supressão total; em 3 de dezembro, o Decreto-lei $\mathrm{n}^{\circ} 1722$ que modificou as condições, termos e formas de aproveitamento do crédito-prêmio; e, em 7 de dezembro, o Decreto-lei $n^{\circ} 1724 / 79$ que conferiu ao Ministro da Fazenda a atribuição de dispor sobre o modo de aproveitamento do crédito-prêmio, sobre o prazo de validade e alíquotas aplicáveis, revogando integralmente os dispositivos contidos no Decreto-lei n ${ }^{\circ} 1658 / 79 .{ }^{2}$

Com esteio na delegação prevista no Decreto-lei $n^{\circ} 1724 / 79$, o Ministro da Fazenda expediu as Portarias n ${ }^{\circ}$ 960/79, 78/81, 89/81 e 292/82 que, de forma sucessiva e gradual, tentaram restringir ou extinguir o direito ao crédito-prêmio de IPI.

04. Por força dessa delegação ao Ministro da Fazenda, os particulares recorreram ao antigo Tribunal Federal de Recursos que, no julgamento da Argüição de Inconstitucionalidade $\mathrm{n}^{\circ}$ 109.896, reconheceu a inconstitucionalidade parcial ${ }^{3}$ do artigo $1^{\circ}$ do Decreto-lei $\mathrm{n}^{\circ} 1724 / 79$, uma vez que a delegação contemplou atribuições que somente poderiam ser realizadas mediante a observância do princípio da legalidade estrita.

05. De outra parte, paralelamente à discussão judicial citada que confirmou a permanência do crédito-prêmio do IPI em nosso sistema jurídico, a existência desse incentivo foi igualmente reconhecida pelo Decreto-lei $\mathrm{n}^{\circ}$ 1894/81, ${ }^{4}$ que ampliou o direito à utilização do créditoprêmio do IPI para as empresas comerciais exportadoras que realizassem exportações de produtos nacionais, bem como pelas Leis $\mathrm{n}^{\mathrm{o}} 7739 / 1989^{5}$ e $\mathrm{n}^{\mathrm{o}} 8402 / 92$.

Não bastasse isso, a própria Administração Pública, perfilhando o entendimento da vigência incessante do crédito-prêmio, editou vários atos normativos ora o reconhecendo como forma de pagamento do Imposto sobre a Renda, ora obrigando as empresas a inseri-lo na receita bruta para

2 Essa revogação foi reconhecida, em 27 de agosto de 1980, pela própria Administração Tributária, por meio de parecer elaborado pelo então Procurador Geral da Fazenda Nacional, Dr. Cid Heráclito, que, respondendo a consulta do Ministro da Fazenda, asseverou que o Decreto-Lei $n^{\circ}$ 1658/1979 foi revogado pelo DecretoLei n 1724/1979, vez que este tratou de forma expressa contrária ao previsto naquele.

3 O Excelso Pretório, anos depois, também reconheceu a inconstitucionalidade apenas das expressões do artigo $1^{\circ}$ do Decreto $n^{\circ} 1724 / 79$ que ensejavam a delegação proibida, conforme se pode verificar nos julgados relativos aos Recursos Extraordinários 250.288/SP e 180.828/RS.

4 Inquinado apenas parcialmente do vício inconstitucionalidade, de acordo com decisões do próprio E. STF nos Recursos Extraordinários 250.288/SP e 180.828/RS.

5 Em seu artigo 18, confere nova redação à alínea b, do $§ 1^{\circ}$, do artigo $1^{\circ}$, do Decreto-Lei 1894/1981. 
efeito de apuração do lucro líquido e lucro real.

06. Pois bem, face a tantas sucessões e oscilações normativas, o Poder Judiciário brasileiro foi chamado a se pronunciar sobre a vigência ou não do crédito-prêmio do IPI no ordenamento jurídico nacional, mormente em face (i) de o Decreto-lei ${ }^{\circ}$ 1658/79 estabelecer 30 de junho de 1983 como data para extinção total do benefício e ter sido revogado (ou não) pelos Decretos-leis $n^{\circ} 1724 / 79$ e $\mathrm{n}^{\circ}$ 1894/81; (ii) do teor do art. 41, do ADCT da Constituição da República Federativa do Brasil de 1988, que determinou que fossem revogados, após dois anos de sua promulgação, os incentivos fiscais de natureza setorial não confirmados por lei, (iii) de imprecisões técnicas e dúvidas deixadas pela Lei $n^{\circ}$ 8402/92 e (iv) de atos administrativos normativos de regulamentação da referida lei e do art. 74, da Lei $n^{\circ}$ 9430/96 (depois modificado pelo art. 49, da Lei $n^{\circ}$ 10637/2002).

07. Nesse bojo, o Superior Tribunal de Justiça, no exercício das atribuições que lhe foram constitucionalmente cometidas, assentou entendimento pacífico e iterativo no sentido de que o crédito-prêmio do IPI continuava validamente a existir em nosso ordenamento jurídico, uma vez que, conforme se depreende da ementa dos reiterados julgados, "declarada a inconstitucionalidade do Decreto-lei n ${ }^{\circ}$ 1724/79, ficaram sem efeito os Decretos-leis n ${ }^{\circ} 1722 / 79$ e no 1658/79, tornando-se aplicável o Decreto-lei 491, expressamente referido no Decreto-lei ${ }^{\circ}$ 1894/91, que restaurou o benefício do crédito-prêmio do IPI, sem definição de prazo”.

A guisa de exemplo, mencionem-se, por oportuno, os seguintes pronunciamentos da e. Corte: no Agravo de Instrumento n ${ }^{\circ}$ 250.914/DF, da $1^{\text {a }}$ Turma (DJU 28.02.2000, p. 71), Recurso Especial no 239.716/DF, da $2^{\text {a }}$ Turma (DJU II 25.09.2000, p. 95), Recurso Especial n ${ }^{\circ} 449.471 / \mathrm{RS}$, da $2^{\text {a }}$ Turma ( $D J U$ 16.02.2004, p. 231) e Recurso Especial no 576.873/AL, da $1^{\text {a }}$ Turma (DJU 16.02.2004, p. 224), Recurso Especial no 361.352 (DJU 15.10.2002), Recurso de Agravo $\mathrm{n}^{\mathrm{o}} 416.264$ (DJU 02.04.2002), Recurso Especial $\mathrm{n}^{\circ} 329.127$ (DJU 15.10.2002), Recurso de Agravo $\mathrm{n}^{\mathrm{o}} 470.945$ (DJU 20.03.2003), Recurso de Agravo $\mathrm{n}^{\circ} 400.690$ (DJU 13.02.2003), Recurso de Agravo $\mathrm{n}^{\mathrm{O}} 472.816$ (DJU 29.10.2002), Recurso de Agravo Regimental $\mathrm{n}^{\mathrm{o}} 484.819$ (DJU 13.10.2003), Recurso Especial $\mathrm{n}^{\mathrm{o}} 529.323$ (DJU 01.10.2003), Recurso de Agravo no 484.819 (DJU 30.06.2003), Recurso Especial $\mathrm{n}^{\circ} 440.306$ (DJU 17.12.2002), Recurso Especial $\mathrm{n}^{\circ} 134.170$ (DJU 17.06.2004), Recurso de Agravo Regimental em Especial no 500.117 (DJU 12.02.2004), Recurso Especial n ${ }^{\circ} 159.341$ (DJU 12.06.2000), Recurso 
Especial no 239.716 (DJU 22.08.2000), Recurso Especial no 449.471 (DJU 16.02.2004), dentre dezenas de decisões que poderiam ser enumeradas.

De tal sorte, a matéria passou a ser enfrentada de modo tão intenso, manso e pacífico que, recentemente, o Superior Tribunal de Justiça adotou posicionamento no sentido de negar seguimento a recursos especiais da União Federal que almejavam o reconhecimento da inexistência do créditoprêmio do IPI (v.g.: AG 470.945, $1^{\text {a }}$ Turma. Rel. Min. Humberto Gomes de Barros, DJU de 20.03.2203).

08. Como se vê, a consolidação de jurisprudência pacífica no seio dos Tribunais Superiores, notadamente do Superior Tribunal de Justiça, viabilizou a emergência de um quadro de estabilidade, previsibilidade em relação à matéria, fazendo com que as empresas passassem, com tranqüilidade, a utilizar o crédito-prêmio de IPI mediante (i) restituição, (ii) ressarcimento, (iii) compensação entre tributos e contribuições federais de diferentes espécies e (iv) compensação com débitos de terceiros. No caso de levantamento de dinheiro em espécie, por força do art. 74, da Lei n ${ }^{\circ}$ 9430/96, a Secretaria da Receita Federal haveria de autorizar a utilização dos créditos a serem restituídos.

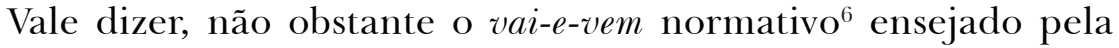
sucessão de Decretos-leis, por meio de uma jurisprudência quinzenária, o e. Superior Tribunal de Justiça, conferindo estabilidade, previsibilidade e segurança, propiciou às empresas confiança e boa-fé na utilização do crédito.

09. Ocorre, entretanto, que, no julgamento do Recurso Especial $n^{\circ}$ 591.708/RS, a Colenda $1^{\text {a }}$ Turma do e. Superior Tribunal de Justiça, embora não tenha havido recentemente qualquer fato novo, tampouco a superveniência de novo diploma legislativo sobre a matéria a justificarem revisão jurisprudencial, ao não reconhecer, em decisão por maioria na qual restou vencido o e. Ministro José Delgado, o direito de utilização do crédito-prêmio do IPI para determinada empresa, dá azo à possibilidade de modificação da reiterada, mansa e pacífica jurisprudência do e. Superior Tribunal de Justiça maculando, assim, a estabilidade, previsibilidade, confiança propiciadas pela consolidação do entendimento iterativo por ela revisto.

Por força dessa decisão isolada ainda não definitiva, a Fazenda Nacional vem propagando que a União Federal buscará recuperar os 6 Expressão utilizada por José Souto Maior Borges. In: Crédito-Prêmio de IPI - Estudos e Pareceres. Barueri: Manole, 2005. p. 56

A \& C R. de Dir. Administrativo e Constitucional, Belo Horizonte, ano 5, n. 22, p. 183-236, out./dez. 2005 
valores do crédito-prêmio do IPI apropriados "indevidamente", por meio da cobrança dos tributos federais que foram quitados mediante compensação com os referidos créditos, manifestando-se, de tal sorte, mais uma vez, a possibilidade de emergência de conflito entre a razão fiscal e a razão jurídico-constitucional.

\section{A consulta}

No bojo da conjuntura acima delineada, honram-me com a formulação de consulta sobre o tema, sendo que os quesitos apresentados a reclamar a presente manifestação opinativa são os seguintes:

(i) De que forma e através de quais mecanismos o princípio da segurança jurídica é tutelado através da Constituição Federal?

(ii) A preservação dos atos praticados no passado pelos particulares e pela Administração Pública e das situações já consolidadas, com vistas à utilização do crédito-prêmio de IPI, realizada com lastro em decisões judiciais e em jurisprudência quinzenária mansa e pacífica, está garantida pelo princípio da segurança jurídica? Através de qual dos seus mecanismos ou institutos?

(iii) Neste contexto, qual é o papel que deve ser atribuído à Jurisprudência mansa e pacífica, que fundamentou a prolação de decisões judiciais favoráveis e a prática de atos de utilização do crédito-prêmio pelo particular, além dos correspondentes atos administrativos por parte da Secretaria da Receita Federal, em relação aos atos pretéritos praticados durante a sua vigência e às situações já consolidadas?

(iv) Eventual mudança de Jurisprudência poderá projetar efeitos para o passado, ocasionando a cobrança de valores decorrentes da utilização do crédito-prêmio de IPI?

(v) Com base na resposta ao quesito anterior, pode-se dizer que as situações já consolidadas ou os fatos consumados, ou seja, os atos de utilização do crédito-prêmio de IPI praticados pelo particular e pela Administração Pública, baseados em decisão judicial favorável e durante a vigência de jurisprudência mansa e pacífica devem ser preservados?

(vi) Como pode ser definida a situação já consolidada ou o fato consumado à luz do princípio da segurança jurídica?

\section{Premissas}

01. Desde logo, cumpre reiterar que a presente análise não visa a discutir o mérito da questão no que tange com a permanência ou não do crédito-prêmio do IPI no ordenamento jurídico. Adota-se, de tal sorte, a premissa de que o e. Superior Tribunal de Justiça poderá acolher a mudança de entendimento jurisprudencial pacificado para extrair as conseqüências que, a partir daí, poderão advir.

02.A Adoção dessa premissa, evidentemente, não implica a assun-
A \& C R. de Dir. Administrativo e Constitucional, Belo Horizonte, ano 5, n.22, p. 183-236, out./dez. 2005 
ção de entendimento favorável ao novo rumo jurisprudencial. Ao contrário, perfilha-se, em consonância com a linha amplamente majoritária do Direito Público nacional, ${ }^{7}$ que o crédito-prêmio do IPI permanece hígido no sistema jurídico brasileiro, havendo sido, portanto, recepcionado pela Lei Fundamental de 1988 e reafirmado pela legislação de regência. De modo que a sustentação de análise a partir do indicativo de modificação jurisprudencial significa tão somente hipótese de trabalho, e não manifestação de concordância com a tese da extinção do crédito-prêmio.

03. Cumpre erigir e enfatizar, ainda, também como premissa da análise que se leva a cabo, a constatação de que o crédito-prêmio de IPI, na condição de relevante incentivo às exportações de produtos nacionais e mecanismo destinado a assegurar a isonomia entre os produtos nacionais e estrangeiros no plano do comércio internacional, representa a concretização de comando, presente na Constituição da República Federativa do Brasil, notadamente em seu artigo 174, que confere ao Estado o papel de agente normativo e regulador da atividade econômica, que pode ser exercido mediante as funções de incentivo e planejamento (intervenção por indução segundo o Ministro Eros $\mathrm{Grau})^{8}$ visando a lograr o desenvolvimento econômico do país.

Deveras, o benefício em tela substancia relevante mecanismo de estímulo seja às exportações de produtos nacionais, seja ao crescimento econômico nacional, seja à criação de empregos, seja à redução das desigualdades, isto é, fomenta atividades que propiciam a implementação de escopos constitucionais da República brasileira.

De tal sorte, essa modalidade de incentivo não constitui uma vantagem ou privilégio, ao revés se apresenta plenamente compatível com a vontade constitucional de promoção de uma política de incentivo às exportações de produtos nacionais. É responsável, em certa medida, pelo incremento da competitividade dos produtos brasileiros nas transações internacionais, auxiliando, assim, o desempenho das exportações.

04 . As considerações que serão tecidas a respeito dos princípios do direito tributário que reforçam a idéia de segurança jurídica não implicam, em momento algum, perfilhar o entendimento de que o crédito-prêmio de IPI teria a natureza tributária e não financeira. Ao revés, quer-se com a argumentação apenas enfatizar a relevância do princípio da segurança jurídica nas relações entre o particular e a Administração Pública.

\footnotetext{
7 Cfr. rol exemplificativo presente em manifestação anterior que integra os estudos e pareceres publicados na obra coletiva Crédito-Prêmio de IPI, op. cit., p.127.

${ }^{8}$ GRAU, Eros. A Ordem Econômica na Constituição de 1988. 9. ed. São Paulo: Malheiros, 2004, p. 84.
} 


\section{Princípio constitucional da segurança jurídica V.1Estado democrático de direito e fundamentação do princípio da segurança jurídica}

01 . Ninguém discorda da natureza profundamente democrática da Carta constitucional de 1988. Não fossem os anseios imperiosos pelo fim da repressão, radica na instituição da nova ordem política a esperança por dias melhores, em que a liberdade de manifestação seja efetivamente exercitável, e, especialmente, a autodeterminação do povo, enquanto liberdade de autogovernar-se, seja realidade. ${ }^{9}$ No seio da nova Constituição, promulgada em 05 de outubro de 1988, encontram-se, portanto, inúmeros dispositivos direcionados para a emancipação do cidadão, para o exercício de direitos e cumprimento de deveres em consonância com a soberania popular.

02. A Constituição é a refundação do Estado Democrático de Direito, não uma refundação instantânea, mas sim o norte de um processo contínuo de construção. Nessa condição, vislumbram-se, em seu bojo, mais do que a disciplina organizatória do Estado, os princípios que regem a relação entre o Estado e o particular e dos particulares entre si, os valores e interesses plurais pressupostos na manifestação coletiva.

03. O conteúdo normativo da Constituição não se realiza por si próprio; é necessária a prática reiterada de condutas que o concretizem, elevem e vivifiquem. É preciso, portanto, vontade de Constituição (Hesse) e cultura constitucional (San Tiago Dantas). A assunção deste compromisso exige engajamento dos atores públicos e privados e perseverança, sem o que nos momentos de crise, a força normativa da Constituição ${ }^{10}$ pode quebrantar. Se é certo que o processo democrático não se encerra na instituição de normas, nem se esgota em rompantes, é certo também que a Constituição, o Estado Democrático e a República requerem estabilidade. Insta construir essa democracia, aperfeiçoar os mecanismos por meio dos quais ela se realiza, consertar as falhas apontadas pela experiência. Analítica ou sintética, a Constituição não guarda apenas as vontades de seus "mentores"; ela é um projeto de Estado, e, portanto, de várias gera-

9 García de Enterria lembra que "un buen sistema democrático es, pues, aquel que se esfuerza en partir de la confianza del pueblo en la designacion de los gobernantes, por supuesto, pero también por mantenerla constantemente viva, como exige la estructura real del trust, fiducia o confianza, de modo que el pueblo se reconozca siempre como titular del poder y beneficiario único de sus actuaciones. El análisis social y el argumento jurídico se apoyan entre sí para llegar a esta conclusión, que es tan importante en el terreno de los principios como en el de las aplicaciones prácticas." (ENTERRÍA, Eduardo García. Democracia, Jueces y Control de la Administración. 4. ed. Madrid: Civitas, 1998, p. 106.)

${ }^{10}$ Conferir, obra clássica da literatura constitucional, HESSE, Konrad. A Força Normativa da Constituição.Tradução de: Gilmar Ferreira Mendes. Porto Alegre: Sérgio Antônio Fabris, 1991. 
ções. Estabilidade que não se confunde com aprisionamento, congelamento, imutabilidade, exige comedimento, cálculo e planejamento.

04. O Direito não é um dado natural, mas sim uma construção cultural $^{11}$ que não prescinde da participação do intérprete na sua resignificação. Os elementos normativos que o compõem, portanto, carecem, com maior ou menor intensidade, de interpretação concretizadora.

05. Embora o Direito não se resuma à Constituição, tem ela como ponto fulcral entre suas mais diversas manifestações. É a Constituição, portanto, que dá o peso e a medida de distintos territórios legislativos fragmentários, permitindo o necessário trânsito entre eles. Daí por que a alteração da Constituição é dificultada; a projeção dos seus efeitos é global.

A vida de uma Constituição depende não só da constante afirmação de sua normatividade, mas também da eficácia dos mecanismos de controle de suas alterações e de inovações infraconstitucionais contrárias a ela. Nessa seara, acresce o papel do Judiciário como protetor da Constituição e da consistência de todo ordenamento jurídico. Acirradas disputas envolvendo diferentes valores e interesses de igual dignidade constitucional fazem parte da realidade democrática e estão presentes nas relações políticas e sociais. Não raro, a solução se dá em sede jurisdicional, devendo ser cenário de esforço harmonizador, de coordenação. O Estado democrático é o espaço natural da manifestação desse pluralismo, daí por que há em seu documento político certa tensão axiológica. O compromisso de proteção da igualdade impõe, também, a proteção das diferenças e, por isso, a tensão antes mencionada tem cunho positivo. Diante disso, tão ou mais importante do que coibir conflitos é criar mecanismos adequados que acomodem os interesses divergentes conferindo alguma segurança às trocas intersubjetivas. O efeito do conjunto desses mecanismos no plano jurídico é a segurança jurídica.

06. Segurança jurídica é uma das razões do Estado, motivo pelo qual é inaceitável que qualquer órgão público pretenda feri-la ou desincumbir-se da tarefa de protegê-la. A despeito da íntima relação, ordenamento jurídico

\footnotetext{
11 "Os fatos jurídicos quer os previstos nos antecedentes das normas, quer os prescritos na fórmula relacional dos conseqüentes, apresentam-se na forma de fenômenos físicos (relações de causa e efeito) mais o sentido, isto é o fim jurídico que os permeia. Sem a significação jurídica que presidiu a escolha do evento e inspirou a regulação da conduta, não há falar-se em fatos jurídicos e relações jurídicas. Essa parte do mundo empírico reivindica tratamento especial, que atente para seu lado dinâmico de ações e reações, no esquema de causa e efeito, mas que também o considere, fundamentalmente, naquilo que ele tem de significação, de sentido." (CARVALHO, Paulo de Barros. O Princípio da Segurança Jurídica em Matéria Tributária. In: MOREIRA FILHO, Aristóteles; LOBO, Marcelo Jatobá (Coord.). Questões Controvertidas em Matéria Tributária. Uma Homenagem ao Professor Paulo de Barros Carvalho. Belo Horizonte: Fórum, 2004, p. 31.)
}

A \& C R. de Dir. Administrativo e Constitucional, Belo Horizonte, ano 5, n. 22, p. 183-236, out./dez. 2005 
e Estado não bastam para existir um ambiente público sólido. Em outras palavras, a não ser em uma concepção formalista, a existência de um Estado de Direito com um sistema normativo operante não é suficiente se não forem qualificados. ${ }^{12}$ Afinal:

la seguridad que deriva de la existencia del Estado no puede localizarse sólo en su condición de poder público componedor de conflictos. EI Estado, que adquiere su máxima expresión en tanto juridificación del poder público, expresa también la seguridad a través de su función de garantía. Por ello, la seguridad en el Estado no podrá ser otra cosa que la seguridad mediante la positividad del Derecho; seguridad, por una parte, previa al conflicto, entendida como la existencia de instrumentos tuteladores de intereses individuales. $\mathrm{Y}$ seguridad, por otra parte, en tanto componedora y armonizadora de tales intereses cuando los mismos colisionen en eventuales conflictos. ${ }^{13}$

07. A segurança jurídica exige, evidentemente, um conjunto normativo público apto a solucionar controvérsias judiciais e, mais do que isso, que os instrumentos disponíveis conduzam a uma decisão justa. Nesse contexto, o reconhecimento de sua dimensão material ${ }^{14}$ ou valorativa é inegável ${ }^{15}$ e a qualifica como um instrumento a serviço dos cidadãos para o controle da atividade jurisdicional.

A virtualidade fática da segurança jurídica exige a busca incessante por equilíbrio entre os caminhos apontados pela experiência para evolução de conceitos, para concretização de justiça e para a estabilidade do direito aplicado em vias de mudança.

08. Ainda que se admita uma tensão entre permanência e ruptura, ${ }^{16}$ entre evolução e segurança, esta é irrenunciável para se perseguir a justiça. Os poderes públicos, por seu turno, estão obrigados a promover as con-

\footnotetext{
12 Federico Blanco ensina que não basta que um Estado respeite e acate as leis e que promova certeza e segurança se não levar em conta fins sociais, preservando não só a estabilidade jurídica, mas também a social. (BLANCO, Federico Castillo. La Proteción de Confianza en el Derecho Administrativo. Madrid: Marcial Pons, 1998, p. 68.)

13 NOVOA, César García. El Princípio de Seguridad Jurídica em Matéria Tributária. Madrid: Marcial Pons, 2000 , p. 23. O autor entende que uma concepção de segurança jurídica formalista não permite sua utilização como critério de valoração de normas. Eis a razão de sua desconfiança em se derivar automaticamente a segurança jurídica da mera existência de um ordenamento jurídico estatal. Ela exige mais, um Estado que seja eticamente aceitável. (Id., p. 24)

${ }^{14}$ Almiro do Couto insere entre os componentes do aspecto material do Estado Democrático de Direito a segurança jurídica, ao lado da idéia de justiça. Entre o sistema de direitos fundamentais, a separação de funções estatais e a legalidade administrativa, componentes do aspecto formal do Estado Democrático de Direito, insere a proteção da boa fé ou da confiança que os administrados têm na ação do Estado, quanto à sua correção e conformidade com as leis. (SILVA, Almiro do Couto e. Princípio da Legalidade da Administração

Pública e da Segurança Jurídica no Estado de Direito Contemporâneo. Revista de Direito Público, n. 84, p. 46).

${ }^{15}$ Carlos Aurélio Mota de Souza afirma que a Segurança é um valor primordial do Direito, especialmente
} 
dições que efetivem a esfera de liberdade e igualdade dos cidadãos, mas sem sacrificar uma delas. Antes, elas precisam ser harmonizadas. ${ }^{17}$

\section{IV.2 Aspectos normativos do princípio da segurança jurídica}

01. Sendo a segurança jurídica corolário do Estado Democrático de Direito, cabe indagar qual sua natureza normativa. Não é fácil definir a segurança jurídica. No entanto, parece não haver maior divergência no reconhecimento de sua dimensão axiológica.

02. Muito embora valor e norma estejam em campos distintos - o primeiro no campo axiológico e a segunda no campo deontológico -, em se tratando de normas constitucionais, especialmente se a norma for de direito fundamental, valor e imperatividade são quase indissociáveis.

A dimensão valorativa de uma norma constitucional, em geral, é mensurada circunstancialmente para sua aplicação. Não se perde em normatividade mesmo quando o peso de um direito recomenda, diante de fatores muito particulares, seu afastamento no caso e a prevalência de outro que joga em sentido contrário. ${ }^{18}$ A definição exata, se regra, princípio ou valor, não comporta resposta encerrada.

03. Conforme o anteriormente asseverado, pode-se intuir que segurança jurídica é valor e também princípio geral diretamente extraível do Estado Democrático de Direito. ${ }^{19}$ Não obstante, ocasiões há em que ela se apresenta como regra de direito fundamental, ensejando sua aplicação certa, sem ponderação. ${ }^{20}$

04. Demais disso, César García Novoa lembra que, provavelmente,

elementos estruturantes da convivência social que, não é demasiado afirmar, o direito concertado com institutos democráticos (i) ostenta a condição de instrumento de sua efetivação da segurança, (ii) ao mesmo tempo que tem sua existência garantida por ela. SOUZA, Carlos Aurélio Mota de. Segurança Jurídica e Jurisprudência. Um Enfoque Filosófico-Jurídico. São Paulo: LTr, 1996, p. 102. No fim desta mesma nota: NATAL, Eduardo Gonzaga Oliveira de. Segurança Jurídica e Certeza do Direito. Um Outro Método de Abordagem em Sede de Direito Tributário. Revista Tributária e de Finanças Públicas, n. 44, maio/jun. 2002, p. 9. Novoa afirma mesmo que o direito, enquanto instrumento de organização social por excelência, é imprescindível para a segurança. (NOVOA, op. cit., p. 21.)

16 "... o ordenamento jurídico é perpassado por uma secular relação de tensão entre permanência e ruptura, estabilidade e mudança, entre o que tende a ser eterno e o que tende à perpétua mudança. Em outras palavras, o ordenamento jurídico, tal qual a vida, equilibra-se entre os pólos da segurança (na abstrata imutabilidade das situações constituídas) e da inovação (para fazer frente ao pânta rei). Assim, na relação (que é fundamental) entre tempo e direito, a expressão 'princípio da segurança jurídica' marca, como signo pleno de significados que é, o espaço de retenção, de imobilidade, de continuidade, de permanência - valoriza, por exemplo, o fato de o cidadão não ser apanhado de surpresa por modificação ilegítima na linha de conduta da Administração, ou por lei posterior, ou modificação na aparência das formas jurídicas." (COSTA, Judith Martins. A Re-significação do Princípio da Segurança Jurídica na Relação entre o Estado e os Cidadãos: a Segurança como Crédito de Confiança. R. CEJ, Brasília, n. 27, out./dez. 2004, p. 113.)

${ }^{17}$ Conferir BLANCO, op. cit., p. 71.

A \& C R. de Dir. Administrativo e Constitucional, Belo Horizonte, ano 5, n. 22, p. 183-236, out./dez. 2005 
não exista outro princípio jurídico tão habitualmente invocado como a segurança jurídica, mas esse, como poucos, manifesta-se com muita indefinição e acentuada carência de conteúdo próprio. ${ }^{21}$

05. O conteúdo do princípio da segurança jurídica, naturalmente mais fluido, quase se confunde, na sua aplicação, com os elementos por meio dos quais se manifesta. No entanto, nada impede que seja invocado diretamente, eis que ostenta a condição de princípio autônomo na estrutura jurídico-constitucional. Esclarecido este ponto, cumpre investigar quais são os princípios e mecanismos a ele atrelados.

Desde logo, ressalte-se não haver um rol taxativo a ser indicado, até porque, como ressalta Carlos Aurélio Mota de Souza, a segurança "não é um critério lógico da estrutura formal das normas, como se fosse elemento impregnado a elas e estático, mas é algo dinâmico que busca a consecução dos bens e dos valores jurídicos, mormente no estado democrático de Direito, como o nosso, a partir da nova ordem constitucional de 1988." 22 06. Antonio Henrique Perez Luño, ${ }^{23}$ César García Novoa, ${ }^{24}$ Almiro do Couto e Silva ${ }^{25}$ e Carlos Aurélio Mota de Souza, ${ }^{26}$ em consonância com grande parte da doutrina, identificam duas dimensões de manifestação do princípio da segurança jurídica. ${ }^{27}$

A segurança jurídica é entendida como sendo um conceito ou um princípio jurídico que se ramifica em duas partes: uma de natureza objetiva e outra de natureza subjetiva. A primeira, de natureza objetiva, é aquela que envolve a questão dos limites à retroatividade dos atos do Estado até mesmo quando estes se qualifiquem como atos legislativos. Diz respeito, portanto, à proteção ao direito adquirido, ao ato jurídico perfeito e à coisa julgada. Diferentemente do que acontece em outros países cujos ordenamentos jurídicos frequentemente têm

\footnotetext{
18 É possível encontrar na doutrina referência a valores e princípios sem qualquer distinção. Tal circunstância é plenamente compreensível, eis que "princípio", mais que um significado técnico-jurídico, possui também um significado vulgar, empregado para indicar algo de grande importância. De outro lado, há na doutrina quem se preocupe em diferenciá-los, tal como Friedrich Müller, em consistente crítica à teoria do valor da doutrina alemã que reconhece a inconstitucionalidade de normas constitucionais. Para um aprofundamento desta questão, que não cabe aqui, conferir ÁVILA, Humberto Bergmann. Teoria dos Princípios: da Definição à Aplicação dos Princípios Jurídicos. São Paulo: Malheiros, 2003; ALEXY, Teoria de los Derechos Fundamentales. Tradução de: Ernesto Garzón Valdés. Madrid: Centro de Estudios Constitucionales, 1997.

${ }^{19} \mathrm{Na}$ Constituição Federal de 1988 nem é preciso extrair implicitamente a segurança jurídica, eis que resta consagrada enquanto princípio autônomo já no caput dos artigos $5^{\circ}$ e $6^{\circ}$, por exemplo.

20 Tal é o caso, por exemplo, da declaração de inconstitucionalidade sem pronúncia de nulidade, na declaração de inconstitucionalidade com efeitos ex nunc e na preservação de certos efeitos de atos administrativos ou normativos declarados nulos em via judicial ou administrativa.

${ }^{21}$ NOVOA, op. cit., p. 19.

22 MOTA DE SOUZA, op. cit., p. 77.

${ }^{23}$ LUÑO, Antonio Enrique Pérez. La Seguridad Jurídica. Barcelona, Ariel, 1991, p.91.

${ }^{24}$ NOVOA, César García. El Princípio de Seguridad Jurídica em Matéria Tributária. Madrid: Marcial Pons, 2000.

25 SILVA, Almiro do Couto e. Princípio da Legalidade da Administração Pública e da Segurança Jurídica no Estado de Direito Contemporâneo. Revista de Direito Público, n. 84.

${ }^{26}$ MOTA DE SOUZA, Carlos Aurélio Mota de. Segurança Jurídica e Jurisprudência. Um Enfoque FilosóficoJurídico. São Paulo: LTr, 1996.

27 "No es de extranar que siendo un principio que da lugar a un derecho cuya satisfacción es posible através
} A \& C R. de Dir. Administrativo e Constitucional, Belo Horizonte, ano 5, n. 22, p. 183-236, out./dez. 2005 
servido de inspiração ao direito brasileiro, tal proteção está há muito incorporada à nossa tradição constitucional e dela expressamente cogita a Constituição de 1988 , no art. $5^{\circ}$, inciso XXXVI.

A outra, de natureza subjetiva, concerne à proteção à confiança das pessoas no pertinente aos atos, procedimentos e condutas do Estado, nos mais diferentes aspectos de sua atuação. ${ }^{28}$ (g.n.)

Tratando a respeito dessas duas dimensões, Perez Luño ${ }^{29}$ salienta que, dentre as exigências objetivas, vislumbram-se a correção estrutural e a correção funcional, sendo que a primeira é função do Legislativo e a segunda, da Administração e Jurisdição; de outra parte, nas exigências subjetivas, as garantias estruturais (Lei) e funcionais (Jurisdição) da segurança objetiva projetam-se, nas situações pessoais, possibilitando aos cidadãos o conhecimento prévio das conseqüências jurídicas dos seus atos, a previsibilidade.

07. Embora não haja unanimidade na discriminação dos elementos que compõem cada dimensão, a divisão pode ser reconhecida, desde que, ressalva amplamente admitida, compreenda-se a interconexão entre eles, ou melhor, seu relacionamento dinâmico na práxis jurídica.

08. No presente estudo, em termos metodológicos, a análise focará os elementos mais pertinentes ao tema da consulta tendo em vista, especialmente, o fato de o crédito-prêmio de IPI ter sido e vir sendo utilizado, mormente, para compensação de tributos federais cujos montantes pretende indevidamente a Fazenda Nacional cobrar. Assim, na dimensão objetiva, destacam-se (i) a previsibilidade e (ii) os princípios específicos do direito tributário. ${ }^{30} \mathrm{Na}$ dimensão subjetiva, o estudo recairá sobre (iii) a confiança legítima e (iv) a boa fé.

\section{IV.3 Dimensão objetiva da segurança jurídica}

\section{IV.3.1 Previsibilidade}

01. A dimensão objetiva da segurança jurídica implica considerar, particularmente, a certeza e a previsibilidade, ${ }^{31}$ sem olvidar, todavia, que ela opera indissociável reflexo no ânimo subjetivo dos cidadãos, mediante

de diversos medios, su contenido se descomponga en microprincipios que se reputan como adecuados para formar parte de esos medios y a través de cuya realización y correcta práctica la propia seguridad jurídica puede llegar a alcanzarse." NOVOA, op. cit., p. 44

28 SILVA, op. cit., p. 273-274.

${ }^{29}$ LUÑO, op. cit., p. 106-107.

A \& C R. de Dir. Administrativo e Constitucional, Belo Horizonte, ano 5, n. 22, p. 183-236, out./dez. 2005 
a idéia de proteção da confiança, desenvolvida inicialmente na doutrina e jurisprudência alemãs. ${ }^{32}$

Há, portanto, entre os efeitos da proteção da segurança nas esferas objetiva e subjetiva, uma patente relação de complementaridade, sem o que não há razão para manter tal dissociação.

02. Importa, neste momento, tratar especificamente da previsibilidade do Direito (dimensão objetiva), a qual se apresenta sob duas perspectivas: "segurança de orientação" e "segurança de aplicação". ${ }^{33}$

03. A denominada "seguridad de orientación" (correção estrutural do Direito) consiste em um conceito mínimo da segurança por meio do Direito. Existente o ordenamento jurídico, tal manifestação abarcará: (i) a existência da norma jurídica, fruto de atividade legislativa racional, voltada para a realidade dos fatos (excluídos, portanto, os vazios normativos e os excessos de uma sucessão temporal, os quais causam inadmissível desconcerto); (ii) a existência de norma anterior ao fato que vai regular; e (iii) o conhecimento da pretensão de definitividade da norma, ou seja, sua estabilidade.

De fato, outra conclusão não há senão a de que a efetividade da segurança jurídica impõe a concretização, ao menos, dessas três exigências conjuntamente. Salta aos olhos que, nesta dimensão objetiva, em face principalmente da tipicidade da norma, não há espaço para discricionariedade administrativa ${ }^{34}$ (muito menos judicial). Ou seja, o esforço legis-

\footnotetext{
${ }^{30}$ A análise desses princípios é pertinente, no caso em tela, mercê do fato de que os montantes decorrentes do crédito-prêmio de IPI, reitere-se, são utilizados para pagamento de tributos federais, sendo, por isso mesmo, levados em consideração quando do provisionamento de valores para essa finalidade.

${ }^{31}$ Para Eduardo Gonzaga, segurança jurídica e certeza diferenciam-se quanto aos efeitos, sendo que a primeira "remete para o futuro no intuito de garantir uma estabilidade quanto às relações jurídicas pendentes de concretização", e a segunda "visa a proteger situações pretéritas, como a coisa julgada, o ato jurídico perfeito, a irretroatividade da lei, etc." Arremata o autor afirmando que antes de princípio, a certeza do direito deve ser entendida como um limite objetivo da aplicação do direito. (op.cit., p. 9). Tendo em conta que a categorização no direito deve atender à finalidade de traduzir de forma legível circunstâncias fáticas complexas, permitindo, assim, facilitar a compreensão do fenômeno, não é recomendável apartar realidades justapostas se disso não resultar em serventia. Diante disso, não será objeto desse estudo diferenciar certeza e estabilidade da segurança, embora seja possível em estudos mais aprofundados sobre o tema.

32 NOVOA, op. cit., p. 73.

33 José Adércio Leite Sampaio reconhece uma dimensão de correção estrutural e outra funcional: "O aspecto objetivo pode ser visto como a finalidade social do direito, reduzida à necessidade de estabilização das expectativas generalizadas de comportamento, seja na perspectiva de realizar a paz e a integração social, seja pelo determinismo de uma mera funcionalidade sistêmica, redutora de complexidades sociais. Outras vezes, é enxergado tanto como exigência de 'correção estrutural' da produção das normas do sistema jurídico quanto 'correção funcional' no cumprimento do direito pelos seus destinatários. O aspecto subjetivo é a "exigência de certeza do direito, tanto no sentido da previsibilidade quanto da garantia das liberdades e dos direitos individuais, especialmente aqueles de cunho patrimonial." (SAMPAIO, José Adércio Leite. Direito Adquirido e Expectativa de Direito. Belo Horizonte: Del Rey, 2005, p. 3.).
} 
lativo, ao exigir ou proibir condutas dos particulares, deve privilegiar a maior clareza possível, excluindo a possibilidade de exigências posteriores fundadas em interpretações convenientes ao Poder Público. Nas relações entre o cidadão e a Administração Pública, clareza e certeza não podem ser suprimidas, eis que, em momentos de "insuficiência de caixa", resultante de políticas alocativas em geral infelizes, a tentação de se aproveitar brechas para legitimar posturas convenientes aos interesses do governo (não propriamente públicas, portanto), aumenta, gerando muitas vezes prejuízos irremediáveis aos particulares.

04. Inconsistências normativas não autorizam interpretações mutantes que, ao sabor da conveniência, causam surpresa aos jurisdicionados. Mas tal situação, embora grave, não é a única a violar o princípio da segurança jurídica enquanto previsibilidade, pois, também o fazem as interpretações mutantes imbuídas de razões mais nobres, quando desatendem critérios razoáveis de transição. ${ }^{35}$ Afinal,

a salvaguarda contra a surpresa exige a periodicidade, que confere aos eventos um mínimo de durabilidade. Por isso, em todas as culturas, o tempo é dividido e contado. Trata-se de dar ao tempo presente uma consistência, fazendo dele um todo extenso e compacto, entre um começo e um fim, dentro do qual os eventos são solidários. ${ }^{36}$

05. Por outro lado, a segurança na aplicação do Direito (correção funcional do Direito) reside, basicamente, no cumprimento do Direito por seus destinatários, especialmente o órgão responsável pela aplicação. Discute-se aqui a metodologia de aplicação que, apesar de não silogística, parte da descoberta da norma aplicável para atuar como premissa maior a ser interpretada. Diante disso, transparece que o processo de aplicação será tão seguro quanto a norma que se aplica.

A essencial manifestação da segurança jurídica, na fase de aplicação da norma, será a interdição da arbitrariedade, seja do ponto de vista formal (subordinação à lei), seja do material (desrespeito ao direito do cidadão de conhecer com rapidez e de acordo com previsões racionais de incidência

\footnotetext{
${ }^{34}$ NOVOA, op. cit., p. 75-79.

${ }^{35}$ Neste sentido, Lucia Valle Figueiredo, analisando a segurança jurídica em face da sucessão de planos econômicos no Brasil, assevera: "mesmo em governos com preocupação social marcada, como determina a Constituição brasileira, não se poderia justificar mudanças descriteriosas a pretexto, à invocação, do interesse público, chamado a contexto sem qualquer suporte." (FIGUEIREDO, Lucia Valle. Planejamento, Direito Tributário e Segurança Jurídica. RDP, n. 12, 1995, p. 12)

${ }^{36}$ (FERRAZ JR, Tercio Sampaio. Anterioridade e Irretroatividade no Campo Tributário. Revista Dialética de Direito Tributário, n. 65, p.125.)
} 
da norma em sua esfera particular). ${ }^{37}$

06. Vislumbra-se, a propósito, claramente um primeiro elemento de manifestação da segurança jurídica que condena surpresas no momento de aplicação do Direito, como ocorre na hipótese da consulta.

\section{IV.3.2 Mecanismos constitucionais de tutela da segurança jurídica na concreção do direito}

01. A infundada pretensão da Administração Pública de recolher tributos que já foram objeto de compensação reclama sejam tecidas algumas considerações a respeito das manifestações do princípio constitucional da segurança jurídica no direito tributário.

Ainda que não houvesse mecanismos concretizadores do princípio da segurança jurídica peculiares a essa seara, os argumentos já expendidos seriam suficientes para proteger a esfera jurídica dos particulares. Tipicidade, irretroatividade e anterioridade, para mencionar alguns, são, então, mecanismos de reforço à tutela da segurança jurídica perante os contribuintes. A fim de evitar reproduções cansativas, passa-se a analisar esses específicos mecanismos naquilo que mais releva. Antes, porém, é preciso ressalvar que a riqueza de sua significação está na aplicação aos casos concretos, ocasião em que é possível aferir as conseqüências necessariamente consentâneas com aquilo que o conjunto de normas abstratas da Constituição requer.

02. Como se sabe, é notória seja, de um lado, a importância do estudo do direito comparado para o aperfeiçoamento de institutos jurídicos pátrios, seja, de outro lado, o desserviço que se presta, muitas vezes, com a tentativa de enraizamento artificial de experiências alienígenas. Portanto, longe de advogar qualquer implantação sem a devida adequação à realidade brasileira, traz-se à colação interessante construção jurisprudencial do Tribunal Constitucional alemão, conclusiva para a configuração normativa da tipicidade.

03. Ante a edição de leis imprevisíveis sobre tributação — surpresa comparável a uma mudança brusca de orientação jurisprudencial —, o Bundesverfassungsgericht, por meio de um juízo ponderativo, decidiu que uma norma com tais características "sólo podría reputarse conforme con la Constitución si existieran claras exigencias de interés general que justificaran que el principio de seguridad jurídica que, insistimos, no es un valor absoluto, debería ceder ante

\footnotetext{
${ }^{37}$ Conferir, nesse sentido, NOVOA, op. cit., p.80-83.
} 
otros bienes o derechos constitucionalmeme protegidos". Da solução encontrada restou ainda a dificuldade de se saber quando motivos de interesse geral teriam legitimidade a ponto de afastar a segurança jurídica.

A propósito, César García Novoa constata que um entendimento equivocado defendendo tratar-se de um conflito entre interesse público e interesse privado poderia levar à conclusão de que o "interesse geral" justifica uma lesão aos direitos dos contribuintes, como se o direito à certeza das situações jurídicas se apoiasse num interesse privado, enquanto que toda reforma legislativa tributária estaria informada por exigências de justiça e interesse público. A premissa, contudo, é enganosa, vez que

la configuración del derecho constitucional a la certeza no puede basarse en una pretendida configuración de las situaciones jurídicas del contribuyente como elementos integrantes de su patrimonio personal. No puede entenderse, por tanto, que el objeto del derecho a la seguridad jurídica sea un interés privado, más allá de su mera estructuración como interés legítimo habilitador de la vía de recurso. ${ }^{38}$

04. O fato de se realizar uma ponderação envolvendo a segurança jurídica é plenamente aceitável em certas circunstâncias, eis que não se trata de um princípio de caráter absoluto. Todavia, suas limitações devem ter sempre por base legítimo interesse público, especialmente quando envolve a expropriação disfarçada na forma de tributação. É evidente que nem toda arrecadação fiscal tem esse semblante, mas tão-somente aquelas realizadas em desrespeito a direitos fundamentais dos cidadãos. Nenhum interesse público pode justificar restrições ordinárias a direitos fundamentais, razão pela qual, enquanto finalidade de todo e qualquer ato do Poder Público, não pode ser por ele, órgão emanador ou fiscalizador, invocado. Na mesma linha, pode-se afirmar que interesses fiscais não podem limitar a segurança jurídica. Caso contrário, no exemplo de César García Novoa, a prescrição da obrigação tributária não existiria.

05. É fundamental a tipificação das condutas constitutivas de fatos imponíveis nas normas que a integram. Daí por que seria, outrossim, requisito essencial que o particular conheça com clareza as conseqüências de seus atos, ou seja, conheça quais são as condutas que ensejam a obrigação de pagar tributo, mesmo porque se trata de assegurar, nesse sítio, a chamada segurança no Direito que se atrela a uma certeza ordenadora, a qual, por sua vez, implica a previsibilidade, a idéia de determinabilidade das conseqüências jurídicas dos atos dos particulares. ${ }^{39}$

${ }^{38}$ NOVOA, op. cit., p. 85.

A \& C R. de Dir. Administrativo e Constitucional, Belo Horizonte, ano 5, n. 22, p. 183-236, out./dez. 2005 
06. No direito brasileiro, por outros caminhos, a previsibilidade constitui elemento fundamental do sistema tributário, sem embargo seja, também, não se olvide, essencial em qualquer relação envolvendo a Administração Pública e o particular.

É cediço, em âmbito internacional, que só ela garante a interdição de arbitrariedade inclusive dos aplicadores do direito.

Quando o ordenamento impõe obrigações específicas que (i) se vinculam a pressupostos de fato relevantes, (ii) substanciam fundamentalmente atos de particulares e (iii) implicam sanção por descumprimento, então tal setor do ordenamento deve prever com a máxima exatidão tanto os pressupostos de fato quanto suas conseqüências jurídicas. O cidadão deve ter conhecimento prévio e pormenorizado para ter certeza da "univocidad de resultados", de tal forma que seu comportamento siga uma regra objetiva fixada legalmente que limite a atuação tanto da Administração quanto dos tribunais. ${ }^{40}$

07. Desenvolvido na tradição alemã, o princípio da tipicidade, na lição de Ricardo Lobo Torres, não se confunde com o princípio da determinação do fato imponível, o qual impõe que todos os elementos integrantes do fato imponível ${ }^{41}$ abstrato devem ser indicados com clareza na lei formal. Assim deve ser para "exigência do tributo pelo fisco e para o conhecimento da extensão da obrigatoriedade pelo contribuinte." ${ }^{42}$ É, pois, uma via única de duas mãos. Aquele (tipicidade) é aberto, não suscetível de definição, só de descrição, uma vez que "representa a média ou a normalidade de uma determinada situação concreta, com suas conexões de sentido." ${ }^{3}$

$\mathrm{O}$ autor faz outra distinção conceitual, relativa agora ao princípio da legalidade, afirmando que "em sentido lato pode abranger os diversos princípios de segurança jurídica: irretroatividade, anterioridade, proibição de analogia etc., mas pela sua relevância e conteúdo, a tipicidade deve ser tratada como princípio específico de segurança jurídica." ${ }^{4}$

08. Não importa aqui adotar postura sobre uma direção certa de

\footnotetext{
${ }^{39}$ Conferir NOVOA, op. cit., p. 103.

${ }^{40}$ Conferir NOVOA, op. cit., p. 113

41 "Fato imponível é o fato concreto, localizado no tempo e no espaço, acontecido efetivamente no universo fenomênico, que - por corresponder rigorosamente à descrição prévia, hipoteticamente formulada pela h.i., — dá nascimento à obrigação tributária.

Cada fato imponível determina o nascimento de uma obrigação tributária.

A lei descreve hipoteticamente certos fatos, estabelecendo os requisitos de sua materialidade. Ocorridos concretamente estes fatos hic et nunc, com a consistência prevista na lei e revestindo a forma prefigurada idealmente na imagem legislativa abstrata, reconhece-se que desses fatos nascem obrigações tributárias concretas. A esses fatos, a cada qual, designamos 'fato imponível'" (ATALIBA, Geraldo. Hipótese de Incidência Tributária. 3. ed. São Paulo: Revista dos Tribunais, 1984, p.64-65.)
} 
conexidade entre os conceitos, seja de legalidade e tipicidade, ou irretroatividade e anterioridade. A interpretação para sua aplicação nos casos concretos prescinde da definição entre gênero e espécie. É suficiente atentar para suas características mais relevantes e, de resto, interpretá-los sistematicamente.

09. Legalidade e tipicidade muito se aproximam, já que aquele tem por conteúdo limitar a cobrança de tributos pelo Estado, autorizando que somente aqueles instituídos por lei possam valer, todavia não basta a existência da lei. Em abstrato, devem-se exaurir os dados que permitem identificar o fato imponível e a quantificação do tributo.

Trata-se de uma reserva absoluta de lei, contrária a qualquer veleidade da Administração na definição da obrigação tributária. Diante disso, compreende Luciano Amaro a tipicidade como outra expressão da legalidade. ${ }^{45}$

10. Tipo é a conexão de sentido entre dados da realidade e uma descrição normativa a eles aplicável. A descrição pode ser mais ou menos ampla para abarcar as semelhanças com o previsto na norma, mas isso deve ser afastado em duas searas do direito: o direito penal e o direito tributário. Nesses dois casos a abrangência do tipo não pode ser elastecida e o ônus de uma possível indeterminação deve necessariamente recair sobre o Estado, nunca sobre o particular. Os bens jurídicos protegidos especificamente em cada caso, mais a segurança jurídica em ambos, autorizam, ou, antes, impõem este entendimento.

11. Quando há tensão entre segurança jurídica e legalidade concreta, é preciso lançar mão do princípio da confiança legítima, trazido a seguir, e ponderar. Mas, desde já, reitere-se que não será possível fazer uso de simplório recurso a colisão entre interesse público versus interesse privado. É preciso manejar o princípio da segurança jurídica eximindo os cidadãos de ônus sempre que a situação instável tiver por causa ato irresponsável do Poder Público (qualquer dos Poderes).

12. Outro princípio com sede especial no direito tributário é o da anterioridade. ${ }^{46}$ Comumente associados, os princípios da irretroatividade e da anterioridade podem ser analisados em conjunto, sem perda de cientificidade para o estudo.

13. É cediço, no meio jurídico, que as normas são feitas para reger o

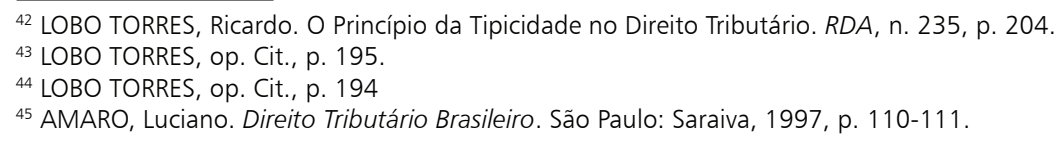


presente e o futuro; somente excepcionalmente projetam seus efeitos para o passado. Em termos gerais, eis o enunciado do princípio da irretroatividade.

Na Constituição de 1988, ele abrange incidência normativa subjetiva (direito adquirido) e objetiva (ato jurídico perfeito), mas não só, protege também eventos pretéritos que não se encaixam em nenhuma dessas categorias. ${ }^{47}$ Quando se fala em segurança jurídica, logo se imagina o tríduo consagrado no art. $5^{\circ}$, inc. XXXVI da Constituição Federal. Porém, é preciso lembrar que seu âmbito de incidência comporta outros pressupostos de fato. O constituinte deixou fora de dúvida essa proteção, inclusive gravada de cláusula de perpetuidade, mas não excluiu, por isso, outros fatos jurídicos que integram a rede de relacionamentos sociais. Até porque tempo, criação humana, não é um valor em si, e deve estar associado a direitos para ter conseqüências juridicamente imputáveis.

14. Diferenciando irretroatividade de anterioridade ${ }^{48}$ no campo tributário, ensina Tercio Sampaio Ferraz Jr. que aquela protege fatos imponíveis anteriores à lei editada, ainda que no mesmo ano; já a segunda mais que representar mero prazo de cobrança e pagamento, protege fatos imponíveis em um mesmo exercício financeiro contra surpresas. ${ }^{49}$

A irretroatividade no campo tributário é uma irretroatividade qualificada:

Na CF vigente, (...) o contribuinte, além desta irretroatividade específica, é protegido também pela irretroatividade do art. 150, III, $a$. Esta não está adstrita ao ato jurídico perfeito (pois, então, teríamos um bis in idem). Prende-se, antes, à doutrina dos facta (no dizer de Pontes de Miranda, referindo-se, na CF de 1969, à irretroatividade penal). Isto é, o contribuinte só pode ser cobrado (eficácia) por força de lei incidente ao tempo do fato, quer no que concerne aos pressupostos típicos, quer quanto à alíquota. Nenhum fato (para maior clareza, nenhum evento) ocorrido antes da vigência da lei nova pode ser apanhado por

\footnotetext{
${ }^{46}$ Tal princípio não se confunde com o da anualidade, já que este significa que nenhum tributo poderá ser cobrado no exercício fiscal sem que a respectiva cobrança esteja prevista no orçamento; enquanto que aquele significa que nenhum tributo será cobrado no exercício fiscal sem que a lei que o instituiu tenha sido publicada no exercício anterior. A propósito, conferir MACHADO, Hugo de Brito. Os Princípios Jurídicos da Tributação na Constituição de 1988. São Paulo: Revista dos Tribunais, 19841989, p. 55; RABELLO FILHO, Francisco Pinto. O Princípio da Anterioridade da Lei Tributária. São Paulo: Revista dos Tribunais, 2002, p. 71-77.

${ }^{47}$ Conferir FERRAZ JR, op. cit., p. 127

${ }^{48}$ Cumpre lembrar que a anterioridade "proíbe que a norma vigente (publicada num exercício financeiro) possa produzir efeitos (eficácia como condição de incidência) no mesmo exercício financeiro, seja sobre fatos/atos ocorridos, no período, antes de sua vigência, seja sobre aqueles que ainda no período, venham a ocorrer após a vigência." (FERRAZ JR., op. cit.), p. 129. Conexo a esses dois princípios, encontramos ainda o princípio da não-surpresa, considerado maior concreção do princípio da legalidade, ou a materialização do princípio da anualidade, somado à anterioridade e a determinação de um prazo fixo (lapso temporal entre publicação de vigência da lei tributária). Para o presente estudo, não demanda aprofundamento. Sobre o assunto, conferir, entre outros MANEIRA, Eduardo. Direito Tributário, Princípio da não Surpresa. Belo Horizonte: Del Rey, 1994.
} 
ela para compor o fato-tipo que ela institui. Aqui a proteção do contribuinte é mais ampla, pois não está em questão o ato jurídico perfeito e acabado. (...) A distinção significa que a proteção conferida, genericamente, pelo art. 150, III, $a$ alcança mais do que atos jurídicos perfeitos e acabados. $\mathrm{E}$ isto faz sentido, em sede de teoria geral do direito, na medida em que um fato não precisa ser ato perfeito para ser fato jurídico, isto é, sofrer a incidência de norma vigente e eficaz. ${ }^{50}$ (g.n.)

15. Como se vê, avulta dessas considerações que o princípio da irretroatividade, na Constituição de 1988, protege tanto o ato jurídico perfeito quanto fatos (eventos) pretéritos. ${ }^{51}$ Calha aqui lembrar haver situações ou estados de fato que não são a rigor direito adquirido, mas sim situações de fundada confiança ou de fundada expectativa em certo comportamento estatal, protegidas pelo princípio da segurança jurídica. ${ }^{52}$

16. De fato, para que um direito seja protegido sob o manto da segurança jurídica, não precisa substanciar efetivo direito adquirido ou ato jurídico perfeito, pois a proteção a direitos no Estado Democrático é ampliativa, só comportando restrições expressas na Constituição ou por ela autorizada. Se essa silencia ou disciplina assistematicamente em seu corpo de modo contrário, não pode a Administração Pública ou o Judiciário se valer da omissão ou falta de clareza para impor obrigações aos particulares.

A alusão à proteção de direitos não adquiridos, mas fundados em um estado de confiança tutelado juridicamente não é construção fantasiosa, mas tese absolutamente plausível, consentânea com nosso sistema de proteção de direitos. Não surpreende, portanto, a disseminação desse entendimento na doutrina nacional. É o caso, por exemplo, de Ingo Sarlet:

a irretroatividade de determinados atos do Poder Público encontra o seu fundamento justamente na necessidade de proteger a confiança do cidadão na estabilidade de suas posições jurídicas e do próprio ordenamento, o que tem levado ao reconhecimento, para além da salvaguarda dos direitos adquiridos, até mesmo de um certo grau de proteção das assim denominadas expectativas de direitos, assim como da necessidade de estabelecer regras de transição razoáveis, nos casos de uma alteração de determinados regimes jurídicos. (g.n.) ${ }^{53}$

17. Em se tratando de direito adquirido ou não, nem sempre é fácil identificar a retroatividade na prática. José Adércio Leite Sampaio relata,

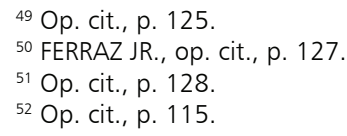

A \& C R. de Dir. Administrativo e Constitucional, Belo Horizonte, ano 5, n. 22, p. 183-236, out./dez. 2005 
ilustrativamente, que o Justice Story desenvolveu o pensamento que levou a Suprema Corte dos Estados Unidos a definir uma "regra geral de interpretação das leis", que facilitou a identificação de leis retroativas quando o Congresso não prescrevesse expressamente seu fim e alcance. Formulou a idéia de que "se a lei prejudicasse os direitos já integrantes do patrimônio das pessoas, se ampliasse a responsabilidade por suas condutas pretéritas ou impusesse novos deveres relativamente a transações já realizadas, seria retroativa." ${ }_{54}$

A Corte americana aperfeiçoou os requisitos, buscando aferir (i) se o legislador foi claro na linguagem normativa para possibilitar ao homem comum identificar a conduta permitida ou proibida; (ii) se o legislador criou uma oportunidade razoável para que as pessoas possam evitar as conseqüências pelo descumprimento da lei, pois se soubesse poderia ter evitado a responsabilidade ou sanção não praticando a conduta; e (iii) se a lei estava imbuída de fins legais racionais. Os três requisitos nada mais são do que derivações da cláusula do due process of law..$^{55}$

18. A útil construção da Suprema Corte estadunidense pode ser manejada, entre nós, sem agressão ao que foi dito sobre importar figuras do direito comparado. Basicamente, dois motivos levam a esse entendimento: (i) a Constituição de 1988 consagra a cláusula do devido processo legal, tanto em sentido formal quanto substancial; (ii) a definição dos requisitos segue necessariamente por um esforço hermenêutico que possibilita sua adequação à nossa realidade.

Assim, para se aferir se houve ou não retroatividade da lei, será preciso delimitar a clareza da linguagem normativa em face do homem comum brasileiro, com as peculiaridades de grau de escolaridade e cidadania aqui existentes. De igual forma, a razoabilidade da oportunidade de conhecimento da norma deve levar em consideração o sistema de publicidade dos atos públicos e a repercussão nos meios ordinários de comunicação. Já em relação ao terceiro requisito aventado pela Supreme Court, é preciso levar em conta que os fins racionais não são a mesma coisa que a intenção do legislador, mas sim a finalidade pública de acordo com os objetivos da ordem jurídico-constitucional.

\footnotetext{
${ }^{53}$ SARLET, Ingo Wolfgang. A Eficácia do Direito Fundamental à Segurança Jurídica. In: ROCHA, Cármen Lúcia Antunes (Coord.). Constituição e Segurança Jurídica - Estudos em Homenagem a José Paulo Sepúlveda Pertence. Belo Horizonte: Fórum, 2004, p. 19-20.

${ }^{54}$ SAMPAIO, op. cit., p. 75-76.

${ }^{55}$ SAMPAIO, op. cit., p. 79
}

A \& C R. de Dir. Administrativo e Constitucional, Belo Horizonte, ano 5, n. 22, p. 183-236, out./dez. 2005 
19. A respeito dos institutos consagrados no inciso XXXVI do art. $5^{\circ}$, pode-se afirmar serem também manifestação da segurança jurídica. Direito adquirido, ato jurídico perfeito e coisa julgada são normalmente identificados como concreção do princípio da irretroatividade das leis. Consagrados pela Constituição de 1988 junto ao rol de direitos fundamentais, o tríduo não gera muitas dúvidas conceituais. De forma sintética, são apresentadas suas definições na Lei de Introdução do Código Civil; todavia o importante é notar que, independente disso, são direitos fundamentais e, como tal, preservados por cláusula pétrea.

20. Se, no plano abstrato, tais institutos não demandam muita controvérsia, no plano prático emergem algumas inconsistências. Para o estudo em tela, torna-se despiciendo descer a minúcias sobre a questão, eis que, como restará demonstrado, atos realizados com respaldo em situação clara de confiança legítima estão protegidos, tutelados pela cláusula da segurança jurídica, entendida ela, em sua dimensão objetiva, como previsibilidade, quanto, na dimensão subjetiva, exposta a seguir. Não há necessidade de subsumir a situação relatada na consulta aos institutos do inciso XXXVI do art. $5^{\circ}$ da Constituição.

Ademais, não é raro os autores que se debruçam sobre o tema concluírem que tais institutos não esgotam a proteção ensejada pelos efeitos da retroatividade, vale dizer, esses efeitos também se espraiam em outros sítios.

\section{IV.4 Dimensão subjetiva da segurança jurídica IV.4.1 Confiança legítima}

01. No direito alemão, desenvolveu-se, primeiramente, o princípio da confiança legítima, entendido como um sistema de defesa do cidadão contra intervenções administrativas, legislativas e também judiciais.

Portanto, o princípio, que, inicialmente, se aplicava ao âmbito administrativo, em casos de colisão entre legalidade e segurança jurídica, ${ }^{56}$ incide, hoje, com suas peculiaridades sobre a atuação dos demais poderes do Estado.

02. No âmbito legislativo, a proteção da confiança "puede limitar el poder del legislador si los inconvenientes que han de sufrir los destinatarios de la norma priman sobre la importancia del objetivo perseguido por ésta y, en consecuencia, se considera como una confianza protegibile." ${ }^{57}$

Com isso, passou-se a defender, também, a proteção dos cidadãos em face de mudanças na jurisprudência dos altos tribunais que poderiam 
provocar uma deterioração das situações legais dos destinatários da norma interpretada. Logo, eles devem poder confiar também na continuidade de determinadas linhas de pensamento jurisprudencial para, em conformidade com elas, pautar suas ações no mundo jurídico e fenomênico. ${ }^{58}$

03. A segurança jurídica, como afirmado, tem dignidade constitucional, aplicando-se de modo vinculante aos poderes públicos e, indistintamente, aos ramos do direito.

No plano fático, certas circunstâncias fundadas na confiança legítima podem encerrar um agravante quando haja violação da segurança jurídica, como ocorre, por exemplo, nos casos que envolvem expropriação do particular, seara típica do direito tributário.

04. Em sede jurisprudencial, a confiança legítima tem o condão de proteger os fatos pretéritos, ${ }^{59}$ visto que proíbe que se aplique entendimento diverso daquele que vinha sendo reiterado, mas que, mercê de uma atualização de sentidos, enseja mudança na orientação. Assim sucede, no sistema espanhol, em que a discussão sobre a existência de verdadeiros precedentes é prescindível, em razão da aceitação de que a jurisprudência (i) vincula juridicamente, ou, ao menos, (ii) possui valor de exemplaridade e (iii) constitui uma via de integração e articulação de todo ordenamento jurídico. ${ }^{60}$

05. Aludindo a essa relação fiduciária entre governo e povo, García de Enterría lembra que, por meio dela, o titular da coisa pública confia a sua gestão às pessoas que elege, mas o objeto da gestão continua sendo a propriedade do povo e seus fins não são outros que os interesses do próprio povo. A confiança é aí essencial e não se entrega de uma vez por todas,

\footnotetext{
${ }^{56}$ Quando a postura do Estado é de passividade, não intervenção na relação de particulares, a segurança jurídica se reveste de estrita legalidade. "Na base da conjuntura formadora do sentido social da segurança jurídica como previsibilidade e certeza dos atos estatais, estavam a radical separação entre a sociedade e o Estado, a relativa estreiteza das funções administrativas, a também relativa estabilidade da produção normativa estatal e a noção de que as relações entre Estado e particulares seriam, nuclearmente, relações de poder, de sujeição ou de subordinação." Eis a conjuntura do Estado liberal em que segurança era previsibilidade com leis abstratas minuciosas (legalidade $X$ autonomia privada). A segurança jurídica era praticamente abstenção da Administração (não atingir ato jurídico perfeito, direito adquirido e coisa julgada, por exemplo, ou "não modificar a prática há longo tempo seguida, se a mudança vier em prejuízo do administrado") (COSTA, Judith Martins, op. cit., p. 114) Estrita legalidade deve ser ponderada com outros princípios, especialmente com o da confiança.

57 BLANCO, op. cit., p. 116

58 BLANCO, op. cit., p. 362

59 O princípio da confiança legítima projeta-se sobre o valor permanência, que, nos dizeres de JUDITH, "constitui-se, com efeito, num valor a ser protegido, pois reflete a confiança considerada como regra do jogo de antemão traçada para ser, no presente e no futuro, devidamente respeitada: sinaliza que essa ordem não permitirá modificações suscetíveis de afetar suas decisões importantes de maneira imprevisível (salvo por razões imperiosas)." (COSTA, Judith Martins, op. cit., p. 113)
} 
"sino que ha de mantenerse viva de forma constante", como o nervo que vivifica e anima a atuação dos gestores e todo o sistema democrático. ${ }^{61}$

Entretanto, a confiança que mantém os laços entre governantes e governados não pode ser uma fé cega; é um crédito social, ${ }^{62}$ uma confiança racional "constantemente renovada, fruto del conocimiento personal y de la acepción cotidiana y permanente de la actuación de los gobernantes (aunque no tenga que ser, naturalmente, una aceptación ni unanime ni que cubra la totalidad de sus decisiones), lo que únicamente puede ser la base eficaz de esa relación." "33

06. O princípio da proteção à confiança só foi identificado como um princípio independente após a segunda guerra, concebido e formado pela jurisprudência.

Inicialmente, o Bundesverfassungsgericht empregou o princípio para limitação da retroatividade de leis e paulatinamente o estendeu para a alteração de jurisprudência. ${ }^{64}$

07. Uma especial função deste princípio foi, desde o início, definida a proteção do particular contra atos inesperados e prejudiciais a quem não deu causa. Segundo Almiro do Couto e Silva, o princípio da proteção à confiança "(a) impõe ao Estado limitações na liberdade de alterar sua conduta e de modificar atos que produziram vantagens para os destinatários, mesmo quando ilegais, ou (b) atribui-lhe conseqüências patrimoniais por essas alterações, sempre em virtude da crença gerada nos beneficiários, nos administrados ou na sociedade em geral de que aqueles atos eram legítimos, tudo fazendo razoavelmente supor que seriam mantidos." ${ }^{65}$

A relação de confiança que se constrói entre o cidadão e a ordem jurídica, fundada em pautas razoáveis de previsibilidade, faz da proteção da confiança legítima um exercício cotidiano de elevada 'pedagogia social', ${ }^{66}$ salutar ao Estado Democrático de direito.

\section{IV.4.2 Proteção da boa-fé}

01. Nas relações de direito público, a boa-fé tem duas posições dis-

${ }^{60}$ Conferir BLANCO, op. cit., p. 365-368.

${ }^{61}$ ENTERRÍA, op. cit., p. 103.

62 "A confiança é, pois, mais que o apelo à segurança da lei, é também mais do que a boa-fé, embora a suponha; é crédito social, é a expectativa, legítima, da ativa proteção da personalidade humana como escopo fundamental do ordenamento." (COSTA, Judith, op. cit., p. 116)

${ }^{63}$ ENTERRÍA, op. cit., p. 110.

64 "o princípio da proteção à confiança apareceu na discussão sobre a revogação de atos administrativos, a vinculatividade de informações da autoridade, a eficácia de contratos administrativos antijurídicos, o efeito externo de prescrições administrativas, a vinculação da administração em sua própria prática, a determinação da propriedade, da fundamentação de um direito de garantia de um plano e - last but not least - a limitação da retroatividade da modificação da jurisprudência judicial superior."(MAURER, Hartmut. Elementos de Direito Administrativo Alemão. Trad. Luís Afonso Heck. Porto Alegre: Sérgio Fabris, 2001, p. 68.)

A \& C R. de Dir. Administrativo e Constitucional, Belo Horizonte, ano 5, n. 22, p. 183-236, out./dez. 2005 
tintas: a da Administração e a do administrado. Nesse bojo, importa, notadamente, a segunda posição, mais especificamente, a repercussão geral da quebra da boa-fé nos administrados. ${ }^{67}$

02. O princípio da boa-fé, cujo campo principal de atuação era, inicialmente, o direito privado, passou a ser compreendido, na doutrina alemã, como passível de aplicação também no campo administrativo.

Sobre o assunto, a obra de Jesus González Perez é paradigmática. ${ }^{68}$ Ensina que a proteção da boa-fé impõe um dever de coerência no comportamento, uma conduta normal, reta e honesta do homem médio a ser medida na relação concreta em que se opera. ${ }^{69}$ Demais disso, assevera que

la aplicación del princípio de la buena fé permitirá al administrado recobrar la confianza en que la Administración no va a exigirle más de lo que estrictamente sea necesario para la realización de los fines públicos que en cada caso concreto persiga. $\mathrm{Y}$ en que no le va a ser exigido en el lugar, en el momento ni en la forma más inadecuados, en atención a sus circunstancias personales y sociales, y a las propias necesidades públicas. ${ }^{70}$

03. É oportuno mencionar um exemplo elucidativo analisado por Gonzalez Perez. Nos anos 90, a Administração espanhola negou a concessão de certas subvenções para medidas de fomento sob o argumento de que haviam sido reguladas por um Real Decreto e noticiadas em campanha publicitária oficial. Nesse caso, muito embora não coubesse ao administrado reclamar o ato em seu benefício, a decisão reconheceu que a Administração certamente outorgou razoável esperança em obtê-las e uma crença na boa-fé, firmando o entendimento de que o administrado não pode ficar sem amparo pelo Direito em situados sob o signo da boa-fé. ${ }^{11}$

Em outra sentença, nos anos 90, o Tribunal decidiu que a bona fides não pode ter sua aplicação limitada aos negócios jurídicos, eis que se trata de um princípio geral e como tal deve orientar a exigência de cumprimento de qualquer obrigação, ainda que derivada de atos administrativos. ${ }^{72}$

Federico Castillo Blanco, em obra monográfica sobre a proteção da confiança, afirma que, na atualidade, o princípio da boa-fé ainda é

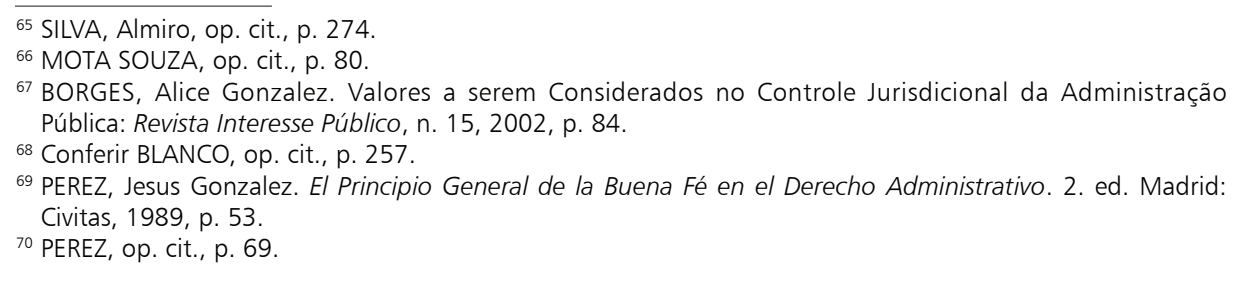

A \& C R. de Dir. Administrativo e Constitucional, Belo Horizonte, ano 5, n. 22, p. 183-236, out./dez. 2005 
utilizado pelos tribunais espanhóis, ainda que em menor freqüência e até com certa confusão envolvendo o princípio da confiança legítima. ${ }^{73}$ Ressalta, outrossim, que o princípio da boa-fé envolve uma relação primária no convívio Estado-cidadão, todavia, atualmente, seria mais adequado trabalhar com a proteção da confiança, encarnado no princípio da segurança jurídica. ${ }^{74}$

04. Desnecessário afirmar que não se está advogando a utilização irracional, sem adequação à realidade brasileira, da experiência alienígena. Ocorre que, da mesma forma que sucedeu na Alemanha, Espanha e outros países europeus, a jurisprudência pode, a partir desse cariz, construir uma teoria capaz de dar conta de nossas peculiaridades.

Deveras, as relações cidadão-Estado são substancialmente distintas entre países democratizados mais e menos desenvolvidos, fato perceptível não só na operacionalização dos sistemas jurídicos, mas também nos problemas econômicos e sociais. No entanto, ao menos dois fatores são análogos: o escopo de alcançar a justiça (grau de desenvolvimento democrático) e manter sua estabilidade (proibição do retrocesso social). Tais fins implicam, em última análise, garantir a segurança jurídica.

05. Mesmo em uma perspectiva civil-constitucional, a análise da jurisprudência pátria sobre a aplicação do princípio da boa-fé, guarda importância. A razão é simples; a aplicação desse princípio tem atributo eticizante que conecta as diferentes searas, permitindo, pela finalidade da sua utilização, exportar resultados comuns.

Diante disso, é salutar mencionar a conclusão de Teresa Negreiros, sustentada em jurisprudência civilista, de que ainda não há uma utilização sistemática deste princípio no Brasil. Tanto boa-fé quanto confiança são usados "com um sentido de flexibilização do Direito, de mitigação de exigências formais e processuais, ainda que se trate de atividade do Poder Público, para cujo desempenho, tais exigências se configurariam como uma garantia de imparcialidade." 75 Ora, o princípio da boa-fé não requer somente o afastamento de arbítrio do julgador, requer também o respeito a um direito fundamental de cunho principiológico que deve ser tutelado de forma ótima, impondo peso às conseqüências da quebra da confiança

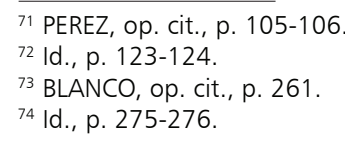

A \& C R. de Dir. Administrativo e Constitucional, Belo Horizonte, ano 5, n. 22, p. 183-236, out./dez. 2005 
que sua ofensa pode gerar. O desenvolvimento do princípio da boa fé no direito civil pode irradiar suas conquistas, desde que adequadas, para o campo do direito público.

Como se vê, a importância dos princípios que traduzem a segurança jurídica, ou suas dimensões, é ímpar, pois se estes forem violados, aquela desaparece. ${ }^{76}$

\section{Jurisprudência e segurança jurídica}

01. Conforme anteriormente explanado, o princípio constitucional da segurança jurídica, em suas dimensões objetiva e subjetiva, permeia todas as relações entre cidadãos e Poder Público, não somente as decorrentes de atuação legislativa e administrativa, mas também da judicial. Não somente o ordenamento jurídico, também a forma pela qual ele é interpretado e aplicado pelos tribunais e órgãos administrativos. Indaguese, de que adiantaria assegurá-la mediante conjunto de leis disciplinando a conduta intersubjetiva, se elas forem aplicadas de modo não uniforme, maculando a confiança criada pelos jurisdicionados em relação a alguns precedentes.

Pretende-se, portanto, levantar, como hipótese de trabalho, quais poderiam ser as conseqüências - e os limites respectivos - provocadas em razão da modificação da jurisprudência de tribunal superior consolidada há muitos anos.

02. Desde logo, saliente-se que, não obstante tenha procedência a idéia de que a atividade judicial, consolidada pela jurisprudência, constitui atividade dinâmica que permite um maior grau de adaptação às mudanças verificadas no espaço e no tempo, comportando a evolução de teorias e concepções adotadas, inclusive sumuladas, não sendo admissível o engessamento, nem a imutabilidade, a alteração significativa de jurisprudência iterativa, mormente no que tange aos seus efeitos em relação a fatos já ocorridos, urge ser ponderada, devendo sofrer limitações de diversas ordens no cotejo com bens e valores constitucionalmente protegidos.

\footnotetext{
75 NEGREIROS, Tereza. Fundamentos para uma Interpretação Constitucional do Princípio da Boa-fé. Rio de Janeiro: Renovar, 1998, p. 238-239.

${ }^{76}$ Em outros termos, afirma Paulo de Barros: "... é possível dizermos que não existirá, efetivamente, aquele valor, sempre que os princípios que o realizem forem violados. Tratando-se de entidades axiológicas, onde, como vimos, o teor de subjetividade é decisivo para identificar resultados, não cabe atinarmos a dados quantitativos, motivo pelo qual não se cogita de saber se uma única transgressão consolidada é suficiente ou se o juízo de reconhecimento requer uma sucessão delas. Os recentes problemas político institucionais por que passou o Brasil, intervalo que se encerrou com o impedimento do ex-Presidente da República, é o melhor exemplo que se pode dar de insegurança das instituições ou, como alguns preferem, de quebra do sobreprincípio da segurança jurídica." (CARVALHO, Paulo de Barros, op. cit., p. 56-57.)
} 
03. Há muito se indaga e também se discute a respeito de possuir ou não a jurisprudência ${ }^{77}$ a natureza de fonte de direito ${ }^{78} \mathrm{e}$, por conseguinte, da vinculação aos precedentes e das diferenças entre os sistemas civil law e commom law. ${ }^{79}$

04. A regra dos precedentes é uma das principais características da argumentação jurídica, inclusive, anota Robert Alexy ${ }^{80}$ que, hodiernamente, a importância, ainda que fática, é reconhecida indistintamente, ${ }^{81}$ apenas há discordância quanto à sua posição teórica, isto é, não é pacífica a atribuição do caráter de fonte formal. Opta, Alexy, por não ingressar na seara de tal discussão, resumindo sua problematização a duas áreas: “(1) o papel a ser atribuído à observação do precedente, como é visto do ponto de vista da teoria do discurso jurídico delineada aqui; e (2) o relacionamento dos argumentos baseados nos precedentes com outros argumentos possíveis do discurso jurídico". ${ }^{82}$

Nesse intento, Alexy ${ }^{83}$ sinaliza que os principais motivos para seguir precedentes são o princípio de universalidade e a exigência de que sejam tratados os casos iguais de forma semelhante; reconhece a possibilidade de, excepcionalmente, não ser seguido o precedente, situação que estará sujeita "à imposição do argumento do encargo", "da justificabilidade pelo argumento”. Propugna, outrossim, que a observância do precedente em caso semelhante, ao assegurar certa estabilidade, possibilita tanto a certeza jurídica, quanto a proteção da credibilidade na tomada de decisão judicial.

\footnotetext{
${ }^{77} \mathrm{Na}$ análise em apreço, embora se trate de uma expressão polissêmica no âmbito da Ciência do Direito, utilizar-se-á o termo jurisprudência como sendo o conjunto de decisões uniformes de um ou vários tribunais sobre a mesma matéria, de forma constante, reiterada e, ainda, pacífica. Conferir, nesse sentido, FRANÇA, Rubens Limongi. Hermenêutica Jurídica. 7. ed. São Paulo: Saraiva, 1999, p. 147-149.

78 "Essa questão é expressivamente respondida na afirmativa por G. Less, Von Wesen und Wert des Richterrechts, Erlangen 1951, p.59 ss.; H. W. Kruse, Das Richterrecht als Rechtsquelle der innerstaatlichen Rechts, Tübingen 1971, p. 7 ss; sobre argumento a favor de uma correção da teoria tradicional das fontes jurídicas, confira também M. Kriele, no local citado, p. 289; Fr. Wieacker, Gesetz und Richterkunst, p. 16 ss; O.A. German, no local citado, p.45 ss.; contra o caráter de precedentes como uma fonte jurídica estão, entre outros, K. Larenz, Über die Bindungswirkung von Präjudizien, p. 247 ss; J. Esser, Richterrecht Gerochtsgebrauch und Gewohnheitsrecht, em: Festschrift f. Fr v. Hippel, Tübbingen 1967, p. 95 ss. Sobre a necessidade de uma abordagem diferenciada, particularmente a respeito da necessidade de 'resolver o problema das fontes da cognição da lei, não de forma abstrata, mas em suas relações com situações e também especificamente com papéis', compare R. Dreier. Probleme der Rechtsquellenhlehre, em: Festschrift f. H. J. Wolff, Munique 1973, p.4 ss" (ALEXY, Robert. Teoria da Argumentação jurídica. Trad. Zilda Hutchinson Schild Silva. São Paulo: Landy, 2001, p. 289)

${ }^{79}$ Embora se trate de tema de extrema relevância, não convém, no presente estudo, haja vista o seu objeto precípuo, tecer considerações aprofundadas sobre a matéria.

${ }^{80}$ ALEXY. Teoria..., p. 258.

81 "N.R. 168 - Compare K. Larenz, Über die Bindungswirkung von Präjudizien, em: Festschrift für H. Schima, Viena, 1969, p.249; O.A.German, Präjudizien als Rechtsquelle. Estolcomo/Götegorg/Uppsala 1960, p.11; M. Kriele, Theorie der Rechtsgewinnung, p.243 ss." (ALEXY, Teoria..., p. 288)
} 


\section{Direito vivo e papel do judiciário}

01. Há forte tendência, notadamente na Itália, articulando a doutrina do direito vivuo, concernente à orientação jurisprudencial da Corte Constitucional italiana segundo a qual, quando da existência de uma interpretação consolidada da disposição legislativa controlada, a Corte adota essa interpretação 'viva', renunciando a interpretar de maneira autônoma a disposição em questão, de modo que as decisões reiteradas forjariam uma espécie de sistema de direito vivo. ${ }^{84}$ Em virtude dessa orientação, a Corte italiana é responsável, sob certas condições, pela aplicação da lei submetida, mais precisamente pela significação que essa lei adquiriu quando de sua aplicação.

Em numerosas decisões, a Corte Constitucional italiana não utiliza a expressão direito vivo, preferindo empregar sinônimos ("jurisprudência dominante", "solução interpretativa corroborada pelos juízes", "significação atual da norma", "disposição legislativa tal qual ela vive na interpretação que lhe deu a Corte de Cassação", "significação adquirida pelo artigo atacado dentro da realidade jurídica viva") por meio dos quais se refere à norma viva como aquela que se afirma historicamente na interpretação e na aplicação concreta de todos os operadores jurídicos e, em particular, dos juízes, de modo a vislumbrar a lei na sua interpretação consolidada. ${ }^{85}$

02. Segundo a Corte Costituzionale para que haja direito vivo, é necessária uma certa concordância na aplicação e na interpretação da disposição legislativa. Uma decisão isolada não pode, em princípio, formá-lo, dado que, por sua natureza, ele depende da constatação de uma orientação dominante no seio da jurisprudência e/ou de outras práticas jurídicas. Não é indispensável, porém, que haja uma uniformidade absoluta das aplicações da disposição. Afinal, para que a significação de uma disposição seja reconhecida como norma viva, ela deve obter adesão e consenso suficientemente elevados e ser utilizada de forma iterativa ao longo do tempo. ${ }^{86}$

03. Antonio Castanheira Neves, por sua vez, ao tratar sobre a função dos assentos no direito português, assevera que: “com os assentos intenta a nossa lei atingir um certo fim, cumprir um determinado objectivo

\footnotetext{
${ }^{82}$ ALEXY. Teoria..., p. 259.

${ }^{83}$ ALEXY. Teoria..., p. 259.

${ }^{84}$ SEVERINO, Caterina. La Doctrine du Droit Vivant. Paris: Econômica, 2003. p. 13.

${ }^{85}$ SEVERINO, op. cit., p. 66
}

A \& C R. de Dir. Administrativo e Constitucional, Belo Horizonte, ano 5, n. 22, p. 183-236, out./dez. 2005 
na ordem das intenções últimas do direito — com a 'uniformização de jurisprudência' visa a conseguir uma unitária estabilidade (ou fixidez) do direito, que satisfaça à segurança jurídica e garanta a certeza de uma unívoca aplicação". ${ }^{87}$

04. O imprescindível papel hodierno da atividade judicial nessa seara decorre, inclusive, da observação de que, no fim do século XVIII e no século XIX, não sendo a sociedade fragmentada e mutante como a atual, o legislador lograva, de certa maneira ainda que não completamente, ${ }^{88}$ prever o que aconteceria, regulando matérias, estabelecendo pautas condensadas em códigos, de sorte que se tem intensificado a proeminência nas sociedades ocidentais da atividade judicante. ${ }^{89}$

Nesse intento, incumbir-lhe-á proporcionar um grau ótimo de segurança aos jurisdicionados e, por conseguinte, uma sensação adequada de elevada confiabilidade em suas manifestações, mitigando em muito a preocupação em torno do risco de existirem decisões antagônicas acerca de uma questão específica, sendo-lhe defeso agir de forma a tornar incertas as relações jurídicas regidas pelo direito material. A ela é inerente a idéia de um direito dinâmico, não refratário a modificações, mas não a idéia de insegurança.

\section{Precedentes no Direito brasileiro}

01 . Ainda que a jurisprudência não ostente, no direito brasileiro, a condição de fonte formal do direito e ainda que não se cogite, a princípio, a existência de um sistema de direito vivo como na Itália, é inegável a sua força como mecanismo estabilizador do Direito, que permite, inclusive, concretizar, viabilizar o atendimento às dimensões, inerentes ao princípio

\footnotetext{
${ }^{86}$ SEVERINO, op. cit.,p. 66-67.

${ }^{87}$ NEVES, Antonio Castanheira. O Instituto dos 'Assentos' e a Função Jurídica dos Supremos Tribunais. Coimbra: Coimbra Ed., 1983, p. 21

${ }^{88}$ Klaus Stern, a propósito, registra: "Se consultarmos o ancestral (moderno) da divisão dos Poderes, o barão francês Charles Montesquieu, conheceremos a sua avaliação do terceiro Poder, do Poder Judiciário, como 'em quelque façon nulle'. Disso resultaram a representação do juiz como 'boca do legislador' e a recusa a todo e qualquer poder judicial de instituição do Direito. Nas codificações prussianas do fim do século XVIII havia até proibições de interpretações e comentários para os juízes, na esteira do Corpus /uris Civilis. Mas essa avaliação da jurisprudência não conseguiu afirmar-se por muito tempo. Já na primeira metade do século XIX ela teve de ceder à idéia de que o poder judicial não é uma mera 'execução' das leis, mas mais, mormente quando a lei é pouco clara ou lacunosa" (STERN, Klaus. O Juiz e a Aplicação do Direito. In: Direito Constitucional - Estudos em Homenagem a Paulo Bonavides. São Paulo: Malheiros, 2001. p. 506).

${ }^{89} \mathrm{Cfr}$. nesse sentido, entre outros: MORO, Sérgio. Jurisdição Constitucional como Democracia. São Paulo: Revista dos Tribunais, 2004; ELY, John Hart. Democracia y Desconfianza. Trad. Magdalena Holguín. Bogotá: Siglo del Hombre Editores; HABERMAS, Jürgen. Direito e Democracia entre Facticidade e Validade. Trad. Flávio Beno Siebeneichler. Rio de Janeiro: Tempo Brasileiro, 1997. v. I.; GARGARELLA, Roberto. La Justicia frente al Gobierno - Sobre el Carácter Contramayoritario del Poder Judicial. Barcelona: Ariel, 1996.
} 
da segurança jurídica, de previsibilidade, calculabilidade, boa-fé confiança em relação ao Estado, que desde sempre vincularam os atos oriundos do Poder Legislativo mercê, aliás, do princípio da legalidade.

Sustenta, nesse aspecto, José Rogério Cruz e Tucci que "para os regimes jurídicos regrados pelo direito codificado, nos quais as decisões judiciais não possuem autoridade vinculante, a técnica de invocar precedentes, se bem utilizada, aumenta em muito a previsibilidade da decisão e, portanto, a segurança jurídica. Opera, outrossim, como importante fato a favorecer a uniformização da jurisprudência." 90

02. Deveras, conquanto a jurisprudência, como conjunto coerente de sentenças, acórdãos e outras decisões, não possa ser fonte formal do Direito como a lei, ela por certo determina papel de estabilização na sua aplicação e interpretação e, assim, influencia consideravelmente as condutas. Afinal,

parece-nos que, contemporaneamente, a principal expectativa que o cidadão brasileiro deposita no Judiciário é a do atendimento aos valores certeza-segurança-estabilidade, o que aliás é bem compreensível, se considerarmos o ambiente de instabilidade presente e imprevisibilidade futura que costuma assombrar nossa sociedade civil. ${ }^{91}$

Tanto é desta forma que a jurisprudência, além de influenciar, muitas vezes de forma decisiva, a produção legislativa, a ação administrativa e o horizonte decisional dos particulares, também pode propiciar outras conseqüências vinculadas à segurança jurídica:

a) para as partes, na medida em que possibilita uma certa previsibilidade quanto à solução final do caso, operando assim como fator de segurança e de tratamento judicial isonômico;

b) para oJudiciário, porque a jurisprudência sumulada agiliza as decisões, alivia a sobrecarga acarretada pelas demandas repetitivas e assim poupa precioso tempo, que poderá ser empregado no exame de casos mais complexos e singulares;

c) para o próprio Direito, em termos de sua eficácia prática e credibilidade social, porque o tratar igualmente as situações análogas é algo imanente a esse ramo do conhecimento humano, certo que o sentimento do justo integra a essência do Direito desde suas origens: jus est ars boni et aequo. ${ }^{92}$

03. Por outro lado, havendo uma estrutura hierárquico-recursal de

\footnotetext{
${ }_{90}$ CRUZ E TUCCI, José Rogério. Precedente Judicial como Fonte do Direito. São Paulo: Revista dos Tribunais, 2004. p. 305.

${ }^{11}$ MANCUSO, Rodolfo de Camargo. Divergência Jurisprudencial e Súmula Vinculante. São Paulo: Revista dos Tribunais, 1999, p. 43.
}

A \& C R. de Dir. Administrativo e Constitucional, Belo Horizonte, ano 5, n. 22, p. 183-236, out./dez. 2005 
tribunais como a brasileira, "é natural que o precedente de tribunal superior exerça um grau de influência maior no âmbito das cortes e juízos inferiores. É claro que o denominado autoprecedente, via de regra, também se impõe, interna corporis, como medida de coerência, além, é claro, da segurança jurídica que deve ser preservada pelos tribunais." ${ }^{93}$

O acesso a um grau de jurisdição superior, inclusive na condição de última instância recursal, confere à decisão a responsabilidade ainda maior de ser coerente, no que tange às teses jurídicas, devendo propiciar segurança mais elevada aos jurisdicionados. Demais disso, consoante a célebre observação do Ministro Victor Nunes Leal, ${ }^{94}$ as causas judiciais iniciadas, seja em momento semelhante, seja em lapso temporal no qual há posicionamento jurisprudencial dominante, revestem-se de intenso grau de probabilidade, funcionalmente importante e necessária, de serem solvidas conforme igual entendimento, sob pena de se acarretar "uma injustiça gritante", sendo conveniente e razoável que "processos iniciados numa mesma época sejam julgados, afinal, pelos mesmos critérios"

04. Desse modo, cogita-se a existência de uma considerável probabilidade, no plano fático, de os juízes singulares e tribunais inferiores seguirem os precedentes dos tribunais superiores e que estes se atenham, por sua vez, à sua própria jurisprudência, o que enseja fidúcia na incidência dessa regularidade aos casos análogos. De tal sorte, os precedentes, mormente os dos tribunais superiores, pelo menos quando não se deparam com uma contradição demasiado grande, são considerados, decorrido algum tempo, 'direito vigente', formando-se em gradativa crescente, como complemento e desenvolvimento do Direito estatuído, um 'direito judicial'. ${ }^{55}$

05. Na medida em que a Constituição Federal prevê a existência dos tribunais superiores e atribui a eles a atividade uniformizadora, não devem, em situações nas quais inexistem fatos e argumentos novos, tampouco superveniência de lei a justificar alteração, os órgãos monocráticos ignorar simplesmente a jurisprudência predominante, quer sob o argumento da não vinculação, quer sob o argumento da liberdade de convicção.

Registre-se, nesse aspecto, inclusive, a cautela adotada pelo Superior Tribunal de Justiça quando se envereda em questões de alteração jurisprudencial, mediante a transcrição de excertos do voto do Ministro Humberto Gomes de Barros, exarado por ocasião de pedido de revogação da Súmula 276 do Superior Tribunal de Justiça:

${ }^{92}$ MANCUSO, op. cit., p. 47.

93 CRUZ E TUCCI, op. cit., p. 305.

${ }_{94}^{4}$ LEAL, Victor Nunes. Problemas de Direito Público e Outros Problemas. Brasília, 1999. v. II, p.57.

A \& C R. de Dir. Administrativo e Constitucional, Belo Horizonte, ano 5, n. 22, p. 183-236, out./dez. 2005 
(...) Outra razão, que adoto como fundamento de voto, finca-se na natureza do Superior Tribunal de Justiça. (...) Saber jurídico a que se refere a CF é a sabedoria que a vida nos dá. A sabedoria gerada no estudo e na experiência nos tornou condutores da jurisprudência nacional. Somos condutores e não podemos vacilar. Assim faz o STF.

Nos últimos tempos, entretanto, temos demonstrado profunda e constante insegurança. (....)

O Superior Tribunal de Justiça foi concebido para um escopo especial: orientar a aplicação da lei federal e unificar-lhe a interpretação, em todo o Brasil. Se assim ocorre, é necessário que sua jurisprudência seja observada, para se manter firme e coerente. Assim sempre ocorreu em relação ao Supremo Tribunal Federal, de quem o STJ é sucessor, nesse mister. Em verdade, o Poder Judiciário mantém sagrado compromisso com a justiça e a segurança. Se deixarmos que nossa jurisprudência varie ao sabor das convicções pessoais, estaremos prestando um desserviço a nossas instituições. Se nós — os integrantes da Corte — não observarmos as decisões que ajudamos a formar, estaremos dando sinal, para que os demais órgãos judiciários façam o mesmo. Estou certo de que, em acontecendo isso, perde sentido a existência de nossa Corte. Melhor será extingui-la. (AEREsp 228432).

Nós somos os condutores, e eu Ministro de um Tribunal cujas decisões os próprios Ministros não respeitam sinto-me, triste. Como contribuinte, que também sou, mergulho em insegurança, como um passageiro daquele vôo trágico em que o piloto que se perdeu no meio da noite em cima da Selva Amazônica: ele virava para a esquerda, dobrava para a direita e os passageiros sem nada saber, até que eles de repente descobriram que estavam perdidos: o avião com o Superior Tribunal de Justiça está extremamente perdido. Agora estamos a rever uma Súmula que fixamos há menos de um trimestre. Agora dizemos que está errada, porque alguém nos deu uma lição dizendo que essa Súmula não devia ter sido feita assim.

Nas praias de Turismo, pelo mundo afora, existe um brinquedo em que uma enorme bóia, cheia de pessoas é arrastada por uma lancha. A função do piloto dessa lancha é fazer derrubar as pessoas montadas no dorso da bóia. Para tanto, a lancha desloca-se em linha reta e, de repente, descreve curvas de quase noventa graus. O jogo só termina, quando todos os passageiros da bóia estão dentro do mar. Pois bem, o STJ parece ter assumido o papel do piloto dessa lancha. Nosso papel tem sido derrubar os jurisdicionados.

Peço vênia para acompanhar o Ministro Peçanha Martins. ${ }^{96}$

06. A estabilidade, como oposto de insegurança, nas decisões judiciais, é elemento de resgate da indispensável fidúcia do jurisdicionado em relação ao Estado-juiz, que detém o monopólio da jurisdição, na medida em que aumenta a confiabilidade, a previsibilidade, a calculabilidade.

\footnotetext{
95 LARENZ, Karl. Metodologia da Ciência do Direito. 3. ed. Trad. José Lamengo. Lisboa: Fundação Calouste Gulbenkian. 1997. p. 611.
}

A \& C R. de Dir. Administrativo e Constitucional, Belo Horizonte, ano 5, n. 22, p. 183-236, out./dez. 2005 
07. Aliás, haja vista a força das reiteradas decisões judiciais fundadas na jurisprudência assentada, nos regimentos internos dos tribunais superiores brasileiros, contempla-se certa força normativa nas súmulas (v.g. RISTF, art. 102 e 103, RISTJ, arts. 122 e 124).

08 . O legislador brasileiro, por sua vez, nessa esteira, passou a conferir relevantes efeitos processuais às súmulas, seja na legislação ordinária (v.g: na redação atribuída pela Lei $n^{\circ} 9756 / 98$ aos artigos 481, parágrafo único, ${ }^{97} 557^{98}$ do diploma adjetivo civil; art. $4^{\text {o }}$, da Lei $n^{\circ}$ 9469/97), ${ }^{99}$ seja no próprio texto constitucional com a redação conferida ao artigo

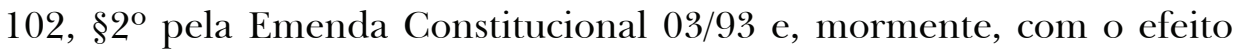
vinculante previsto pela Emenda Constitucional n ${ }^{\circ}$ 45/04 (\$2 ${ }^{\circ}$ do artigo 102 tanto para Ação Declaratória de Constitucionalidade, quanto para a Ação Direta de Inconstitucionalidade e art. 103-A prevendo a súmula vinculante no âmbito do e. Supremo Tribunal Federal).

Como se vê, gradativamente, confere-se uma maior força vinculante aos precedentes jurisprudenciais e, assim, almeja-se evitar que a insegurança possa persistir ou que exista em níveis mais suportáveis nas relações entre os cidadãos e Estado-juiz.

09. Diante do quadro, é compreensível que a jurisprudência possa gerar uma "convicção de obrigatoriedade" ${ }^{100}$ que, embora não se cogite que ela seja fonte formal de direito, conjugada com a boa-fé e confiança dos cidadãos, implica conseqüências, mormente em um sistema como o brasileiro que admite institutos como o incidente de uniformização de jurisprudência, as súmulas e a respectiva atribuição de efeitos vinculantes; que confere, ao relator do feito, poder para negar seguimento de recurso em dissonância com jurisprudência pacificada e que, igualmente, diante da jurisprudência, autoriza o Poder Público a deixar de interpor recurso ou propor demanda, a despeito do princípio da indisponibilidade do interesse público.

\footnotetext{
${ }^{96}$ AgRg no REsp. 382.736/SC, Rel. Min. Francisco Peçanha Martins, DJ 25/2/2004, Primeira Seção do STJ.

97 "Art. 481 - (...) Parágrafo único: Os órgãos fracionários dos tribunais não submeterão ao plenário, ou ao órgão especial, a argüição de inconstitucionalidade, quando já houver pronunciamento destes ou do plenário do Supremo Tribunal Federal sobre a questão".

98 Possibilidade de o relator denegar, monocraticamente, seguimento a recurso que esteja em descompasso com jurisprudência pacificada. Neste sentido, dentre outros: Sandro Marcelo Kozikoski. Manual dos recursos Cíveis - Teoria Geral e Recursos em Espécie. 2. ed. Curitiba: Juruá, 2004, p. 276 et seq.

${ }_{99}$ Admissibilidade de dispensa de propositura, pelo Advogado-Geral da União, de ação ou interposição de recursos quando a controvérsia jurídica estiver iterativamente decidida pelo Supremo Tribunal Federal ou Tribunais Superiores.
}

A \& C R. de Dir. Administrativo e Constitucional, Belo Horizonte, ano 5, n. 22, p. 183-236, out./dez. 2005 


\section{Decisões judiciais sobre o crédito-prêmio de IPI}

01 . Analisada a força, a importância em termos de segurança jurídica conforme anteriormente explanado e a convicção de obrigatoriedade da jurisprudência no Brasil, cumpre salientar que, em relação ao créditoprêmio de IPI, as decisões judiciais que se reiteraram ao longo de considerável lapso temporal foram e são fundamentais e imprescindíveis à construção de um quadro de estabilidade.

02. Desde logo, não se olvide que se está a tratar acerca de lides que envolveram e envolvem discussões quanto à manifestação ou não de revogação tácita, uma vez que, conforme explanado no item contextualização, coube ao Poder Judiciário decidir, solvendo a instabilidade e as dúvidas existentes, sobre a revogação do Decreto-lei no 1658/79 que, em sua redação original, estabelecia 30 de junho de 1983 como data para extinção total do benefício, em virtude da superveniência dos Decretos-leis $n^{\circ}$ 1724/79 e $n^{\circ} 1894 / 81$.

Deveras, o particular teve ciência de uma definição estatal em relação à citada revogação e, por conseguinte, quanto à manutenção do crédito-prêmio de IPI, por meio justamente de decisões reiteradas que se consolidaram ao longo dos anos e reconheceram e ainda reconhecem a vigência dele.

03. Como se sabe, é inerente a todo ato normativo, que o legislador elabora, insere no ordenamento e que apresenta conteúdo colidente ou substitutivo de lei anterior, o efeito revocatório. Esse efeito pode ser expresso, mediante a identificação no próprio ato dos dispositivos que restam revogados (v.g.: fica revogado o dispositivo tal), ou tácito quando a norma de revogação está implícita (não há rol taxativo expresso) e ele se realiza seja em virtude de incompatibilidade, seja em razão de nova disciplina integral da matéria. Tal regramento encontra-se previsto no art. $2^{\circ}$, da Lei de Introdução ao Código Civil:

Art. $2^{\circ}$ - Não se destinando à vigência temporária, a lei terá vigor até que outra a modifique ou revogue.

$\S 1^{\circ}$ A lei posterior revoga a anterior quando expressamente o declare, quando seja com ela incompatível ou quando regule inteiramente a matéria de que tratava a lei anterior.

$\S 2^{\circ}$ A lei nova, que estabeleça disposições gerais ou especiais a par das já existentes, não revoga nem modifica a lei anterior.

\footnotetext{
$\overline{100}$ ASCENÇÃO, José de Oliveira. O Direito - Introdução e Teoria Geral. 7. ed. Coimbra: Almedina, 1993. p. 303.
} 
$\S 3^{\circ}$ Salvo disposição em contrário, a lei revogada não se restaura por ter a lei revogadora perdido a vigência.

04. No caso em tela, envolvendo discussão quanto à revogação tácita, é acentuada a importância das decisões reiteradas para a viabilização e o respeito à segurança jurídica nas relações jurídicas intersubjetivas construídas em torno do crédito-prêmio do IPI.

05. Vale dizer, não obstante a deficiente redação dos Decretos-leis que cuidaram da matéria, seja por envolver hipótese de revogação tácita, seja pelas oscilações, pelo vai-e-vem normativo, a consistência da jurisprudência iterativa, mansa e pacífica assentada pelos tribunais superiores, notadamente o Superior Tribunal de Justiça, propiciou que fosse assegurada a segurança jurídica em sua dupla dimensão, na medida em que não só ensejou previsibilidade, estabilidade, mas também a legítima confiança dos jurisdicionados em relação ao benefício.

06. Com esteio e confiança nessas decisões reiteradas no decorrer de mais de quinze anos, ${ }^{101}$ os interessados elaboraram, concretizaram e concretizam seu planejamento econômico, contábil e financeiro considerando e contemplando referidos créditos, entendidos como líquidos e certos, para desenvolver suas atividades, pagar credores e compensar débitos tributários.

Deveras, as empresas têm se estruturado econômica e financeiramente levando em conta o montante correspondente a esse crédito, seu planejamento estratégico tem-se arrimado na legítima previsão da incorporação daquele benefício; de igual sorte, a atração de investidores nacionais e estrangeiros e a captação de recursos no mercado de capitais fulcram-se em lançamentos contábeis, projeções e simulações que, por sua vez, prevêem tal incentivo.

07. Não se olvide, outrossim, que essa fidúcia em relação à jurisprudência quinzenária do crédito-prêmio confirma-se e se fortalece consideravelmente em razão da plena consonância do incentivo com a Constituição de 1988, que aponta para o desenvolvimento econômico nacional e a realização dos objetivos fundamentais da República mediante a concessão de incentivos que estimulem as exportações de produtos nacionais.

\footnotetext{
${ }^{11}$ A guisa de exemplo, em decisão exarada recentemente, em 18 de maio de 2005, o MINISTRO JOÃO OTÁVIO DE NORONHA negou seguimento a agravo em recurso especial interposto pela União Federal, com esteio na jurisprudência consolidada do STJ reconhecendo a vigência do Decreto-Lei n 491/69 prevendo o crédito-prêmio do IPI com prazo indeterminado. (ref. AGRAVO DE INSTRUMENTO No 593.254 - DF)
} 


\section{Eventual guinada jurisprudencial: limites eficaciais IX.1 Considerações iniciais}

01 . Na medida em que a hipótese definida para a realização desse estudo consiste na possibilidade de modificação da jurisprudência reiterada ao longo de anos em relação ao crédito-prêmio de IPI, convém não olvidar que se, de um lado, o princípio da segurança jurídica não tem o condão de engessar, amarrar ou bloquear, de forma definitiva, o Direito e a jurisprudência, admitindo-se, assim, modificações de orientação interpretativa judicial, tal não implica, por outro lado, que esse princípio não deva ser levado em conta nas situações concretas.

E, no plano global, também em vista da segurança jurídica, a mudança de orientação jurisprudencial, em gerando a substituição da “convicção de obrigatoriedade" tida pelo Administrador Público e cidadãos em relação ao entendimento que se remove, haverá de nortear as suas condutas apenas para o futuro. Isso porque, nas decisões individuais os casos concretos permitem o aproveitamento de dados da realidade, o que não ocorre no plano geral da eficácia produzida pela jurisprudência.

02. A admissibilidade da redefinição nos padrões de atuação da Administração Pública diante de modificações jurisprudenciais, inclusive, por exemplo, em relação à interpretação e aplicação de normas tributárias e financeiras, não dá azo a que esse novo padrão de conduta administrativa, determinado por uma convicção de correção da jurisprudência, possa projetar-se para o passado (aos fatos que já ocorreram), devendo, portanto, projetar-se para o futuro, mesmo porque, no caso em tela, em muitas oportunidades, a própria Administração Pública agiu reconhecendo a não extinção do crédito-prêmio em 1983. É defeso, destarte, ao Poder Público, com base em modificação do norte da interpretação judicial, rever atos administrativos consolidados, até porque foram esses também fundados e gerados com base na boa-fé, confiança diante da atuação estatal e expectativa de estabilidade inerente ao papel da jurisprudência.

03. Deveras, a jurisprudência consolidada no sentido da permanência do incentivo após 1983, mercê de sua estabilidade ao longo de mais de quinze anos, conferiu aos jurisdicionados não somente previsibilidade, calculabilidade, mas também a justa, razoável e consistente confiança na manutenção do entendimento e no direito de igual tratamento. Inclusive porque, ao erigir jurisprudência iterativa, sólida e coesa 
no sentido da manutenção do crédito-prêmio de IPI, o Poder Judiciário adimpliu com a função de garantir a segurança jurídica, em virtude da previsibilidade (essencial) dos julgamentos sobre o assunto, e com isso, por outro lado, serviu de esteio para a orientação (elemento de fidúcia) de muitas empresas na sua atuação e na tomada de decisões econômico-financeiras.

Destarte, emerge indagação necessária, imprescindível, a propósito do risco de criação de panorama de ostensivo desequilíbrio, provavelmente não visado pelo legislador tampouco pelo julgador, ao particular que arcará com prejuízos incomensuráveis.

04. Pois bem, diante dessa conjuntura, é necessário reconhecer, como ponto de partida, que a proteção ao princípio da segurança jurídica não tem o condão de impedir mudanças, não havendo óbice à alteração do entendimento do e. Superior Tribunal de Justiça em relação a temas que já se encontrem consolidados jurisprudencialmente, desde que, evidentemente, haja fundamentação jurídica razoável e consistente a justificála (o que, como já ressaltado, não será objeto de consideração no presente estudo, sem embargo se subscreva o entendimento conducente à constatação de não haver tal esteio argumentativo, devendo ser mantida a jurisprudência iterativa).

05. Se é certo que, no quadro da atividade jurisdicional, o Poder Judiciário pode rever seus posicionamentos, eis que o Direito e a sociedade são dinâmicos, não se pode olvidar, igualmente, que se trata de Poder inserido no quadro do Estado Democrático de Direito e, portanto, comprometido com direitos fundamentais e valores tutelados pela Constituição.

Com efeito, a atividade judicante, ao conferir respostas, soluções concretas, confere à sociedade o caminho da estabilidade, da segurança nas relações intersubjetivas. A fortiori, na situação do crédito-prêmio de IPI, razões de segurança jurídica, impositivas de calculabilidade, mensurabilidade, estabilidade, previsibilidade e confiabilidade na atuação do Poder Público, não tolerantes das surpresas, embora não impliquem a imutabilidade ou o engessamento no sentido de impedir mudanças legislativas, administrativas, jurisprudenciais, não podem ser, por isso, ignoradas. As situações consolidadas devem ser mantidas.

06. Não se olvide, outrossim, que os créditos em tela têm sido aproveitados em contexto de confiança dos particulares em relação aos aparatos e normatividade estatais, seja em razão da normal aquiescência da própria Administração Pública, seja, mormente, com esteio na conviçcão de 
obrigatoriedade gerada pela jurisprudência consolidada, bem como, por iguais razões, têm sido objeto imprescindível de consideração para efeito das programações levadas a cabo pelos jurisdicionados.

07. A questão, portanto, que se coloca cinge-se aos limites eficaciais de eventual mudança na linha reiterada do entendimento do e. Superior Tribunal de Justiça quanto à matéria. Isto é, há que se indagar quanto à extensão dessa hipotética guinada jurídica.

\section{IX.2 Limites eficaciais e Direito brasileiro}

01 . Nesse intento, cumpre, antes de mais nada, inclusive com escopo de promover cotejo e elaborar raciocínio análogo, não olvidar alguns mecanismos existentes no direito brasileiro em relação à questão da mudança interpretativa/jurisprudencial e à aplicação de efeitos prospectivos ao revés de retroativos, quais sejam: vedação à aplicação retroativa de nova interpretação (inciso XVIII, do parágrafo único do artigo $2^{\circ}$ da Lei $\mathrm{n}^{\mathrm{o}}$ 9784/99; ${ }^{102}$ artigo $146,{ }^{103}$ do Código Tributário Nacional) e possibilidade de modelação de efeitos na hipótese de declaração de inconstitucionalidade.

Trata-se de hipóteses nas quais, na atividade administrativa e judicante, embora haja a proclamação de um novo entendimento em oposição à reiterada jurisprudência, ele se aplica para casos futuros.

03. No que concerne à modelação, vale registrar que, quando se admite um Direito principiológico que implica ponderação, mais dúctil, como diz Gustavo Zagrebelsky, ${ }^{104}$ e quando se percebe que a segurança jurídica não decorre apenas do Direito enquanto objeto, mas sim da argumentação; em síntese, quando se abre todo o sistema jurídico, é preciso ter um mecanismo de fechamento que garanta alguma segurança jurídica. Hoje não é mais possível sustentar um mecanismo de fechamento baseado na delimitação e na regulação estrita das categorias jurídicas. A complexidade social atingiu um ponto em que o fechamento vai ocorrer notadamente em função da última palavra a ser dada pelo órgão de cúpula do Poder Judiciário. Eis a razão da presente verticalização do Judiciário brasileiro.

04. Pois bem, entendia-se há até pouco tempo que o controle de

\footnotetext{
102 "Art. $2^{\circ}-(\ldots)$

Parágrafo único: Nos processos administrativos serão observados, entre outros, os critérios de: (...)

XVIII - interpretação da norma administrativa da forma que melhor garanta o atendimento do fim público a que se dirige, vedada a aplicação retroativa de nova interpretação".

103 "Art. 146 - A modificação introduzida, de ofício ou em conseqüência de decisão administrativa ou judicial, nos critérios jurídicos adotados pela autoridade administrativa no exercício do lançamento somente pode ser efetivada, em relação a um mesmo sujeito passivo, quanto a fato gerador ocorrido

A \& C R. de Dir. Administrativo e Constitucional, Belo Horizonte, ano 5, n. 22, p. 183-236, out./dez. 2005
} 
constitucionalidade ensejava um juízo declaratório de reconhecimento de uma patologia preexistente e, por isso, a declaração da inconstitucionalidade implicava, inexoravelmente, produção de efeitos ex tunc. No entanto, no Brasil, a inconstitucionalidade em tese pode ser declarada a qualquer momento e, dado o fato, já anunciado, de que a sociedade hoje é mais complexa, plural e fragmentada, é muito possível que uma lei que nasceu constitucional, tenha transitado para um estado de inconstitucionalidade em virtude da mudança das circunstâncias fáticas. É muito possível, por outro lado, que a declaração de inconstitucionalidade de uma lei crie uma situação de injustiça muito mais grave do que a própria manutenção da inconstitucionalidade, como, por exemplo, a hipótese daquele cidadão que faz um concurso público e é investido num cargo criado por lei inconstitucional e que, vinte anos depois, vê, para seu espanto, a declaração de inconstitucionalidade da lei.

Para que a declaração de inconstitucionalidade não faça tábula rasa do que aconteceu no tempo pretérito, erigiu-se uma distinção entre a eficácia no plano normativo e a eficácia no plano das relações concretas (plano normado). ${ }^{105}$ A declaração de inconstitucionalidade produz efeitos ex tunc no plano normativo, mas não desconstitui necessariamente os atos praticados, as situações jurídicas de vantagem emergidas sob a sua égide. Essas situações precisariam sofrer um processo de desconstituição à luz do devido processo legal, o que enseja a seguinte ponderação: de um lado o princípio constitucional da nulidade dos atos inconstitucionais e de outro lado os direitos e situações que foram consolidadas e a idéia de segurança jurídica. E dessa ponderação emergiria a regra a regular o caso concreto.

05. A propósito, o Excelso Pretório fez, em algumas oportunidades, temperamentos ao então dogma da nulidade dos atos inconstitucionais. Fazendo uso da teoria da aparência (funcionário de fato), o Supremo não invalida os atos praticados pelo servidor investido, por força de lei inconstitucional, em cargo público. Inexistindo prejuízo, protegia-se a aparência de legalidade dos atos em favor da boa-fé e segurança jurídica de terceiros (RTJ 200/1086 e RTJ 71/570). Outro temperamento também decorria do respeito à coisa julgada. Afigurava-se como certo que a nuli-

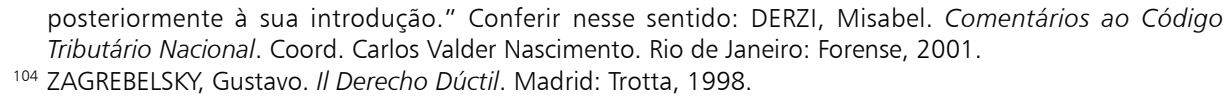

A \& C R. de Dir. Administrativo e Constitucional, Belo Horizonte, ano 5, n. 22, p. 183-236, out./dez. 2005 
dade ex tunc não afetava - como até hoje não afeta - a norma concreta contida na sentença ou no acórdão transitado em julgado. Igualmente, outros temperamentos foram admitidos diante de casos que envolviam situações juridicamente consolidadas.

06. Mais recentemente, as Leis $\mathrm{n}^{\circ} 9.868 / 99$ e $\mathrm{n}^{\circ}$ 9.882/99 passaram a prever no Brasil a manipulação dos efeitos da decisão no plano do processo abstrato. Ressalte-se, a decisão é declaratória no que diz respeito ao reconhecimento da inconstitucionalidade, mas é constitutiva quanto à definição dos efeitos. Portanto, por economia processual, com a aprovação de dois terços dos seus membros, pode o Supremo Tribunal Federal manejar os efeitos da decisão para (i) declarar a inconstitucionalidade com eficácia apenas ex nunc; (ii) com eficácia ex tunc; ou (iii) com eficácia retro-operante até determinado momento — não necessariamente até o início da produção de efeitos pela lei ou a data da promulgação. ${ }^{106}$ Pode, inclusive, se for o caso, (iv) declarar a inconstitucionalidade sem pronúncia da nulidade, dando prazo para que o legislador promova a promulgação de uma nova lei para evitar eventual situação de lacuna jurídica, que poderia ser mais grave.

07. Com efeito, a relativização da eficácia das decisões judiciais em face do caso concreto, mediante ponderação de seus efeitos em cotejo com outros bens e valores constitucionalmente protegidos (aqui considerada, inclusive, a segurança jurídica), não é novidade no Direito pátrio (doutrina, legislação e jurisprudência). Aliás, no artigo $27,{ }^{107}$ da Lei $n^{\circ} 9868 / 99$, que admite a restrição-modulação dos efeitos da declaração de inconstitucionalidade, há expressa menção ao princípio da segurança jurídica.

A doutrina, a fortiori diante desse dispositivo, vem admitindo a possibilidade da técnica decisional da declaração de inconstitucionalidade sem pronúncia de nulidade, além da restrição temporal dos efeitos da decisão (mediante, por exemplo, atribuição de eficácia ex nunc), situações em que se ponderam, para eventual fim de limitação, os efeitos da declaração de inconstitucionalidade em face, no caso citado, da segurança jurídica e da verificação de excepcional interesse social. A modelagem dos efeitos da decisão vem sendo admitida, inclusive, em sede de processo subjetivo, concreto, como já advertido pelo Ministro Gilmar Mendes (Medida Cautelar em Ação Cautelar - AC 189 MC /SP).

08. Em sede de juízos de ilegalidade, idêntica situação se manifesta,

\footnotetext{
105 CLÈVE, Clèmerson Merlin. Fiscalização Abstrata da Constitucionalidade no Direito Brasileiro. 2. ed. São Paulo: Revista dos Tribunais, 2000. p. 253.

${ }^{106}$ Art. 27 da Lei n 9.868/99.
}

A \& C R. de Dir. Administrativo e Constitucional, Belo Horizonte, ano 5, n. 22, p. 183-236, out./dez. 2005 
sendo oportuno esclarecer que, para a solução dos casos concretos envolvendo a problemática dos efeitos de um ato passível de invalidação, é necessário certa dose de criatividade. ${ }^{108}$ Por isso, Weida Zancaner já lecionava, em longa passagem de citação imprescindível, o seguinte:

Os limites ao dever de invalidar surgem do próprio sistema jurídico-positivo, pois, como todos sabemos, coexistem com o princípio da legalidade outros princípios que devem ser levados em conta quando do estudo da invalidação.

Claro está que o princípio da legalidade é basilar para a atuação administrativa, mas como se disse, encartados no ordenamento jurídico estão outros princípios que devem ser respeitados, ou por se referirem ao Direito como um todo, como por exemplo, o princípio da segurança jurídica, ou por serem protetores do comum dos cidadãos, como por exemplo, a boa-fé, princípio que também visa protegê-los quando de suas relações com o Estado.

Assim, em nome da segurança jurídica, simetricamente ao que referimos quanto à convalidação, o decurso de tempo pode ser, por si mesmo, causa bastante para estabilizar certas situações fazendo-as intocáveis. Isto sucede nos casos em que se costuma falar em prescrição, a qual obstará a invalidação do ato viciado. Esta é, pois, uma primeira barreira à invalidação.

Por sua vez, o princípio da boa-fé assume importância capital em razão da presunção de legitimidade dos atos públicos, presunção esta que só cessa quando esses atos são contestados, o que coloca a Administração Pública em posição sobranceira com relação aos administrados.

Ademais, a multiplicidade das áreas de intervenção do Estado moderno na vida dos cidadãos e a tecnicização da linguagem jurídica tornaram extremamente complexos o caráter regulador do Direito e a verificação da conformidade dos atos concretos e abstratos expedidos pela Administração Pública com o direito posto. Portanto, a boa-fé dos administrados passou a ter importância imperativa no Estado Intervencionista, constituindo, justamente com a segurança jurídica, expediente indispensável à distribuição da justiça material. É preciso tomá-lo em conta perante situações geradas por atos inválidos.

Com efeito, atos inválidos geram conseqüências jurídicas, pois se não gerassem não haveria qualquer razão para nos preocuparmos com eles. Com base em tais atos certas situações terão sido instauradas e na dinâmica da realidade podem converter-se em situações merecedoras de proteção, seja porque encontrarão em seu apoio alguma regra específica, seja porque estarão obrigadas por algum princípio do Direito. Estes fatos posteriores à constituição da relação inválida, aliados ao tempo, podem transformar o contexto em que esta se originou, de modo a que fique vedado à Administração Pública o exercício do dever de invalidar, pois fazê-lo causaria ainda maiores agravos ao Direito, por

\footnotetext{
107 "Art. 27. Ao declarar a inconstitucionalidade de lei ou ato normativo, e tendo em vista razões de segurança jurídica ou de excepcional interesse social, poderá o Supremo Tribunal Federal, por maioria de dois terços de seus membros, restringir os efeitos daquela declaração ou decidir que ela só tenha eficácia a partir de seu trânsito em julgado ou de outro momento que venha a ser fixado".

108 LLORENTE, F. Rubio. La Jurisdición Constitucional como Forma de Cración del Derecho. Revista Espanhola de Derecho Constitucional, n. 22, 1988, p. 36 et seq.
} 
afrontar à segurança jurídica e à boa-fé. ${ }^{109}$

09. Como se vê, não é novidade, no direito brasileiro, que o princípio da segurança jurídica pode (e deve) servir de barreira aos efeitos das decisões judiciais e administrativas, como sucede na declaração de inconstitucionalidade sem pronúncia de nulidade, na declaração de inconstitucionalidade com efeitos ex nunc e na preservação de certos efeitos de atos administrativos ou normativos declarados nulos pela via judicial ou administrativa.

10. Destarte, em havendo a emergência de nova jurisprudência em substituição a que restou consolidada ao longo de mais de quinze anos, situação que apenas se admite, reitere-se, a título de hipótese de trabalho, mercê (i) da confiança em relação aos precedentes iterativos, (ii) da previsibilidade por eles proporcionadas, (iii) da necessidade de se impedir ofensa ao princípio da isonomia, (iv) de se salvaguardar razoável e justo equilíbrio dos interesses em jogo, (v) de se impedir um rompimento brutal na segurança estabelecida pelos arestos, o novo entendimento não poderá se aplicar a situações fáticas já ocorridas e que se arrimaram na jurisprudência anterior, operando apenas efeitos prospectivos.

\section{IX.3 Proteção da confiança legítima, prévio conhecimento e efeito anúncio}

01. Não bastasse isso, a indagação a respeito da extensão temporal dos efeitos de eventual modificação em jurisprudência iterativa, mansa e pacífica merece ser permeada por considerações tecidas, notadamente no direito europeu, conforme anteriormente analisado no item IV e no presente item relembrado, a propósito da proteção da confiança legítima, que não é senão corolário do princípio da segurança jurídica, a qual se encontra, por sua vez, imbricada com o princípio da publicidade e, assim, com a idéia de efeito anúncio. É oportuna essa análise também para realizar um cotejo entre a eficácia imediata de uma nova jurisprudência e a

\footnotetext{
109 ZANCANER, Weida. Da Convalidação e da Invalidação dos Atos Administrativos. 2. ed. São Paulo: Malheiros, 1993, p. 61-63. Conferir, nesse sentido: Almiro do Couto e Silva (Prescrição Qüinqüenária da Pretensão Anulatória da Administração Pública com Relação a seus Atos Administrativos. Revista de Direito Administrativo, n. 204, p. 21 et seq.), Juarez Freitas (Estudos de Direito Administrativo. São Paulo: Malheiros, 1995, p. 9 et seq.), Celso Antônio Bandeira de Mello (Curso de Direito Administrativo. 4. ed. São Paulo: Malheiros, 1993, p. 238), Lúcia Valle Figueiredo (Extinção dos Contratos Administrativos. São Paulo: Revista dos Tribunais, 1993, p. 92), Miguel Reale (Revogação e Anulamento do Ato Administrativo. Rio de Janeiro: Forense, 1980, p. 28-29).
} 
eficácia imediata e retroatividade das leis.

02. Pois bem, ao tratar dos requisitos necessários à existência de um mínimo de segurança no Direito, César García Novoa ${ }^{110}$ reconhece que não basta haver a norma, tampouco é suficiente que ela exista em caráter prévio à produção dos fatos que ela regula, sendo indispensável que essa existência prévia seja conhecida por seus destinatários e eventuais realizadores dos pressupostos de fato nela previstos, até em razão do princípio da publicidade, e, também, seja regular com pretensões de definitividade. Atrelada a isso, a vedação à arbitrariedade implica o rechaço de situações nas quais, ainda que não se infrinja a hierarquia normativa, menoscabe-se o direito do cidadão ao conhecimento mais célere possível e mais consoante com suas racionais previsões de incidência do que pode ensejar em sua esfera individual a aplicação de determinada norma jurídica. ${ }^{111}$

03. Deveras, nas relações com a Administração Pública, é imprescindível que o particular conheça com clareza as conseqüências de seus atos, é dizer, saiba quais são os comportamentos concretos a que o ordenamento vincula, por exemplo, o dever de pagar tributo e/ou o direito de reaver valores pagos e quais as formas e mecanismos que podem ser adotados para tanto, tal como a compensação, o que, evidentemente, conduz à idéia de determinabilidade e previsibilidade das conseqüências jurídicas dos atos dos particulares.

Trata-se de prever, de fixar quais são as obrigações e direitos, por conseguinte, quais são os montantes a pagar e as formas pelas quais tais pagamentos podem ser realizados, permitindo, de tal sorte, o planejamento fiscal, a programação econômico-financeira do particular. ${ }^{112}$ Havendo, de outra parte, ofensa à confiança dos jurisdicionados em uma prévia delimitação de seus deveres fiscais e, assim, ao princípio da segurança jurídica, quando sucede, por exemplo, imprevisível alteração de elementos essenciais da obrigação como o quantum debeatur. Articulam-se, portanto, em termos de interdependência, com mais intensidade, nas relações entre a Administração Pública e o particular, as dimensões subjetiva e objetiva do princípio da segurança jurídica, em síntese, a previsibilidade e a fidúcia do jurisdicionado.

04. No caso em tela, reitere-se, esses escopos e ao mesmo tempo dimensões inerentes ao princípio da segurança jurídica foram logrados

\footnotetext{
110 NOVOA, op. cit., p.75-6

111 NOVOA, op. cit., p. 82
}

A \& C R. de Dir. Administrativo e Constitucional, Belo Horizonte, ano 5, n. 22, p. 183-236, out./dez. 2005 
justamente por meio da consolidação da jurisprudência reiterada, mansa e pacífica concludente pela permanência da vigência do crédito-prêmio de IPI. As empresas nela se arrimaram ao exercer sua atividade econômica e, inclusive, nela se pautaram para o processo geral de tomada de decisões.

05. Flavio López de Oñarte ${ }^{113}$ denomina de preordenamiento normativo um dos requisitos essenciais da certeza das normas positivas, consistente em que elas devam existir e serem conhecidas pelos destinatários previamente à produção dos fatos que lhe são objeto de regulação, o que enseja necessidade de apreciação dos conflitos entre retroatividade e segurança jurídica.

A possibilidade de o cidadão calcular os efeitos de sua atuação é, a princípio, incompatível com a existência de normas cuja vigência estendase a condutas anteriores a sua edição, mormente porque, no momento da realização dos atos, era impossível conhecer o conteúdo das futuras leis, ${ }^{114}$ de modo a apenas se atender, a princípio, à exigência de previsibilidade do ordenamento (dimensão objetiva) mediante normas que atuam pro futuro. Eis o porquê da grande aversão à retroatividade e da emergência dos princípios da anterioridade, tipicidade anteriormente tratados. Limitações à retroação que se fortalecem em virtude de eventual colisão das disposições retroativas com o direito do particular à certeza.

06. Afinal, haja vista que os fatos e atos que, segundo a lei, ensejam o nascimento e a extinção de obrigações são inerentes ao exercício, pelo cidadão, de sua liberdade pessoal e econômica, as suas conseqüências devem ser conhecidas no momento em que ele a exerce, concretizando seus negócios.

07. Por outro lado, conforme alerta César Novoa, ${ }^{115}$ há situações em que, por força da mutabilidade das relações, é necessária a redefinição da arrecadação de receita tributária, que, por vezes, não se pode concretizar mediante normas meramente prospectivas, razão pela qual existem muitos intentos no sentido de erigir teorias que mitiguem os riscos inerentes à legislação com efeitos retroativos.

A propósito, o Tribunal de Justiça das Comunidades Européias, ${ }^{116}$ com o escopo de estabelecer limites à eficácia ex tunc, condiciona a admis-

\footnotetext{
112 Permitir "que el particular pueda planificar fiscalmente su conducta y, si así lo estima oportuno, condicionar por motivos tributários, las decisiones referentes a su actividad econômica" (NOVOA, op. cit., p. 117)

113 OÑARTE, Flávio López. La Certeza del Derecho. Trad. de S. Sentis Melendo y M. Ayerra Redín. Buenos Aires: Ediciones Jurídicas Europa-América, 1953. p. 78. O Tribunal Constitucional espanhol, na sentencia 136/1989, utiliza expressão semelhante, qual seja predeterminácion normativa.

114 Conferir nesse sentido: LUÑO, Antonio Enrique Pérez. La Seguridad..., p. 91.
} 
sibilidade da retroatividade ao devido respeito à confiança legítima do administrado e a que o próprio fim da norma exija de forma inequívoca o caráter retroativo e que isso reste justificado devidamente.

08. Com efeito, a dimensão subjetiva do princípio da segurança jurídica, que o denota como proteção da confiança dos cidadãos, que organizam sua conduta econômica de acordo com a legislação vigente, diante de mudanças normativas razoavelmente imprevisíveis, erige-se como principal limite à retroação. ${ }^{17}$

09. A doutrina e a Corte Constitucional alemãs têm, enfática e insistentemente, almejado estabelecer mecanismos de comunicação entre os direitos à certeza, à proteção da confiança e a eventual retroatividade de normas. Para tanto, consideram o princípio da segurança jurídica na sua dimensão subjetiva de certeza e proteção à confiança como correspondente à exigência de que o cidadão possa prever antecipadamente o quantum que desembolsará. ${ }^{118}$

10. Desse modo, incumbiria verificar, no caso concreto, se é digna de proteção a confiança na inalterabilidade da norma do particular que condicionou e ajustou sua conduta econômica à legislação e a jurisprudência então vigentes.

A existência de proteção à confiança, por sua vez, dependeria da constatação de ser a modificação levada a cabo algo esperado ou não pelo jurisdicionado, isto é, ser ou não do seu efetivo conhecimento prévio. Sendo, portanto, de fundamental importância nessa seara a idéia de efeito anúncio (Ankündigungseffekt), isto é, corolário do princípio da publicidade que consiste na utilização de mecanismos de divulgação que permitem dar ciência ao particular a respeito da futura produção de modificação normativa, uma vez que não haveria possibilidade de invocar a segurança jurídica em face da atuação do legislação quando se tratasse de agravação fiscal conhecida e esperada por todos. ${ }^{119}$

11. Aliás, mesmo nas hipóteses em que o efeito anúncio logre viabilizar esse conhecimento prévio do jurisdicionado em relação à futura alteração normativa, cogita-se, outrossim, mercê do princípio constitucional da segurança jurídica, a adoção de consistentes regimes transitórios. ${ }^{120}$

12. Como se vê, a proteção da confiança como óbice à retroatividade

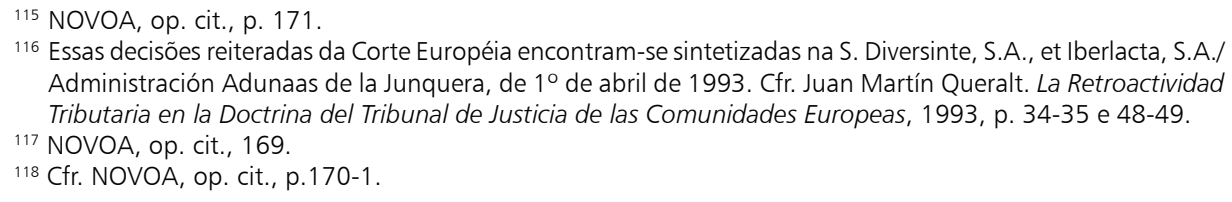


de modificações normativas e jurisprudenciais está estreitamente vinculada à existência ou não de conhecimento prévio por parte do particular da modificação vindoura.

13. Pois bem, de igual sorte, no caso em apreço, sem embargo não se pretenda meramente transplantar ao direito brasileiro tais considerações e decisões dos tribunais europeus, é pertinente indagar se ao interessado, em relação ao crédito-prêmio de IPI, foi conferida a possibilidade de antever a (eventual) guinada considerável da jurisprudência em relação a esse crédito. Há como cogitar ter havido um conhecimento prévio e até se havia possibilidade de viabilizá-lo?

Nesse aspecto, conforme exaustivamente ressaltado acima, não se olvide ser inegável a relevância da jurisprudência iterativa, pacífica e mansa na viabilização de situação de certeza, previsibilidade, confiança em relação à questão do crédito-prêmio de IPI, mormente em razão da sucessão de diplomas normativos, das indagações concernentes à revogação e aos efeitos do reconhecimento parcial da inconstitucionalidade.

Acrescente-se, outrossim, que inclusive os ilustres Ministros, que prolataram a decisão isolada, não unânime e ainda não definitiva, no RESP 591.708, em confronto com a jurisprudência consolidada sobre o assunto, em decisões anteriores, perfilharam o entendimento iterativo. Não se olvide, ainda, que, recentemente, foram proferidas decisões na linha da jurisprudência reiterada (v.g.: AI n ${ }^{\circ}$ 593254/DF).

14. Não bastasse isso, saliente-se que a situação concreta é ainda mais delicada e problemática, porque a eventual adoção do entendimento propugnado nessa decisão isolada não afeta somente o entendimento dos tribunais superiores existente até então, que gerou uma razoável fidúcia de permanência ao jurisdicionado que atuou conforme ele, mas sim afeta à própria normatividade que arrimou tais decisões, chegando, inclusive, a eliminá-la do ordenamento e, enfim, macula a própria atuação judicante que ora viabiliza a previsibilidade, a confiança legítima, ora menoscaba as suas próprias decisões anteriores e, assim, afeta o que dantes proporcionou.

15. Diante dessa conjuntura, é possível afirmar insofismavelmente que, no caso em tela, era completamente imprevisível, e até impossível prever, a emergência de modificação da jurisprudência quinzenária sobre o crédito-prêmio de IPI, de sorte a se descartar, de plano e integralmente, 119 NOVOA, op. cit., p. 179

120 BANACLOCHE, Julio Palao. La Seguridad Jurídica, n. 20. In: Jura Benéfica. Editorial La Ley, 1997, p. 1. 
a possibilidade de conhecimento prévio das empresas que o utilizam consideravelmente nas suas dinâmicas negociais, tanto que o planejamento, a estruturação, as avenças celebradas foram por elas levados a cabo com a certeza, a segurança de utilização dos créditos.

Aliás, tratando-se de decisão judicial isolada, órfã , certamente, não se poderia cogitar sequer a viabilidade de adoção do efeito anúncio, a fim de afastar a proteção da confiança legítima dos jurisdicionados em relação a tais decisões pacíficas, reiteradas que reconheceram a inexistência de revogação do crédito.

16. Como se vê, a confiança merecedora de proteção em relação à jurisprudência reiterada, caso essa seja superada, permite vislumbrar a aplicação da proposta de Knittel, ${ }^{121}$ no sentido de que os fatos já ocorridos no passado, na consonância com a jurisprudência de até então, sejam decididos em conformidade com ela, havendo, apenas, o anúncio quanto ao estabelecimento de novo entendimento sobre o assunto.

17. A par disso, na medida em que o impacto de uma eventual mudança nessa jurisprudência equivale, e até, quiçá, supera muito, ao que seria ensejado por uma alteração legislativa, eis que as empresas têm planejado, organizado seus negócios, estruturado suas finanças, suas projeções de equilíbrio patrimonial, captado recursos considerando esse direito ao crédito-prêmio, é plenamente possível associar a emergência eventual de uma nova jurisprudência a situações consumadas no passado (isto é, exportações já realizadas de produtos nacionais) aos mecanismos inerentes à irretroatividade das leis em seu sentido amplo.

Com efeito, o impacto dessa eventual jurisprudência será assaz considerável, visto que afetará elemento primordial não somente de sustentabilidade dessas empresas, mas também de promoção, desenvolvimento e intensificação da política de exportações decorrente de ditames constitucionais, tendo, ainda, lamentavelmente, graves e imprevisíveis repercussões macro-econômicas.

De tal sorte, torna-se razoável e pertinente, ainda que não seja possível cogitar um engessamento das decisões judiciais até em razão da dinamicidade que lhe é e deve ser inerente, admitir, em certa medida, a aplicação analógica dos limites à retroatividade previstos no artigo $5^{\circ}$, inciso

121 Cfr. KNITTEL, Zum Problem der Rückwirkung bei einer Änderung der Rechtssprechung, 1965, p. 50 et seq.

A \& C R. de Dir. Administrativo e Constitucional, Belo Horizonte, ano 5, n. 22, p. 183-236, out./dez. 2005 
XXXVI, vedando, no caso em apreço, à nova jurisprudência a incidência em situações pretéritas.

18. Destarte, seja em razão dos dispositivos legais, mormente o artigo 146 do CTN, que impedem a retroação de nova interpretação, seja em razão dos relevantes motivos — dentre eles a própria segurança jurídica — que justificam a modelação dos efeitos e, assim, a não aplicação de efeitos ex tunc, seja porque se constata haver, no caso em tela, situação na qual deve ser tutelada a confiança legítima, não mitigada por eventual efeito anúncio, caso venha eventualmente a prevalecer a decisão isolada oriunda do RESP $\mathrm{n}^{\mathrm{O}} 591.708$, incumbirá ao novo entendimento não somente respeitar situações pretéritas já consumadas relativas às exportações de produtos nacionais já realizadas, mas também erigir um período transitório que propicie às empresas envolvidas a adequação de suas condutas, avenças, planejamentos, o que, não se olvide, é plenamente compatível com os requisitos previstos nas leis recentes que prevêem a modelação dos efeitos da declaração de inconstitucionalidade, quais sejam excepcional interesse social e segurança jurídica.

\section{Sínteses conclusivas}

Em resumo, diante de tudo o que se afirmou, é possível condensar as seguintes conclusões:

A. A segurança jurídica é princípio constitucionalmente protegido.

B. A segurança jurídica é tutelada, na Constituição da República, por meio de elementos e institutos que podem ser compreendidos em duas dimensões. Na dimensão objetiva, destacam-se (i) a previsibilidade e (ii) os princípios específicos do direito tributário; ${ }^{122}$ na subjetiva, (iii) a confiança legítima e (iv) a boa fé;

C. Não há um rol exaustivo dos elementos por meio dos quais se manifesta o princípio constitucional da segurança jurídica;

D. As dimensões objetiva e subjetiva devem necessariamente ser compreendidas em relação de interdependência e intercomplementariedade;

E. A previsibilidade espraia-se, especialmente, em duas situações, quais sejam: a correção estrutural, atinente ao plano normativo, e a correção funcional, concernente ao campo da aplicação do Direito;

F. Tipicidade, anterioridade e irretroatividade, além do direito 
adquirido, do ato jurídico perfeito e coisa julgada, são manifestações objetivas do princípio da segurança jurídica impeditivas de arbítrio de qualquer dos poderes estatais;

G. Os princípios da confiança legítima e da boa-fé, que não se confundem, protegem a esfera privada do cidadão em face de atos imprevistos, prejudiciais e/ou não legítimos praticados pelo Poder Público;

H. A segurança jurídica, em todas as suas dimensões, orienta a produção legislativa (normatividade primária), mas também a administrativa e judicial, bem como as relações jurídico-privadas.

I. Da mesma forma, mesmo quando no caso sob julgamento judicial não estejam em jogo as situações de proteção específica da segurança jurídica, esse princípio deve servir para o fim de limitar a eficácia das decisões concretas, como sucede no caso da declaração de inconstitucionalidade com eficácia ex nunc, na declaração de inconstitucionalidade sem pronúncia de nulidade ou nas hipóteses em que doutrina e jurisprudência admitem a preservação de efeitos dos atos declarados nulos (relativização dos efeitos da nulidade), seja, neste último caso, por meio da via judicial ou administrativa.

J. A segurança jurídica, ainda no plano da atuação judicial, aparece implícita no papel estabilizador da jurisprudência, enquanto conjunto de decisões coerentes e de posicionamentos jurídicos pacificados que geram "convicção de obrigatoriedade" e de correção.

$\mathrm{K}$. Por isso que, independentemente das decisões judiciais concretas, a jurisprudência presta-se a orientar a conduta do Poder Público (aqui, inclusive, do Judiciário) e dos particulares.

L. Neste caso, a mudança de orientação jurisprudencial, em face do próprio princípio geral da segurança jurídica, deverá produzir efeitos, caso o Administrador Público, o Legislador ou o próprio Judiciário resolvam observá-lo, apenas para o futuro, por imposição de previsibilidade, calculabilidade e proteção da confiança e da boa-fé.

M.Logo, por exemplo, se a Administração, com base em jurisprudência, costumava considerar reiteradamente certo crédito lícito e legítimo (caso do crédito-prêmio do IPI), reconhecendo-o de

\footnotetext{
${ }^{122}$ Reitera-se, aqui, o que foi dito na nota $n^{\circ} .30$.
}

A \& C R. de Dir. Administrativo e Constitucional, Belo Horizonte, ano 5, n. 22, p. 183-236, out./dez. 2005 
forma estável, não pode, em face de alteração jurisprudencial que a declare ilegítima, pretender, por meio do não reconhecimento das compensações já efetivadas, buscar ressarcimento de montantes utilizados pelos particulares. A modificação da jurisprudência, assim, poderá orientar a sua atuação futura, diante da demanda de calculabilidade e previsibilidade, mas jamais alcançará o passado.

N. Da mesma forma, nas hipóteses em que o debate relativamente ao crédito-prêmio do IPI esteja sob discussão judicial ainda não transitada em julgado, em vista do princípio geral da segurança jurídica, haverá o Poder Judiciário de considerar os créditosprêmio já consolidados, de modo a lançar mão, igualmente, dos mecanismos anunciados de restrição eficacial da decisão.

O. Referidas limitações, inclusive, também servirão, por idênticos fundamentos, para obstar a pretensão da Administração no que tange com aplicação de sanção de multa em decorrência de autuação por lançamento de créditos supervenientemente considerados, pela Fazenda Pública, como indevidos.

P. A possibilidade excepcional de retroação encontra-se condicionada ao efetivo respeito e proteção da confiança legítima, o qual se dá apenas quando o cidadão tem conhecimento prévio, viabilizado por exemplo pelo efeito anúncio, da modificação normativa e/ou jurisprudencial, eis que, dessa forma, lograria adaptar suas atividades comerciais, econômicas e financeiras, seu planejamento ao novo entendimento

Q. No caso do crédito-prêmio, em relação à decisão isolada proferida no RESP 591.708, haja vista a ausência absoluta de previsibilidade e conhecimento prévio dos interessados, que restaram surpreendidos com a decisão, vez que a jurisprudência pacífica, iterativa no decorrer de anos, inclusive acompanhada pelos próprios Ministros que ora preconizaram esse novo entendimento isolado, a proteção à confiança legítima e à boa-fé, bem como a própria dignidade da Justiça, como mecanismo que propicia o respeito ao princípio da segurança, exigem que o entendimento veiculado nesse julgado, ainda que seja reiterado, opere efeitos meramente prospectivos, incidindo apenas sobre situações ocorridas após o seu advento e o respectivo conhecimento dos jurisdicionados em relação a isso. 


\section{Resposta aos quesitos}

Diante de todo o exposto, as respostas aos quesitos formulados são as seguintes:

Quesito 1. De que forma e através de quais mecanismos o princípio da segurança jurídica é tutelado através da Constituição Federal?

Resposta: A segurança jurídica deve ser compreendida como princípio constitucional, corolário do Estado Democrático de Direito. Em certas circunstâncias, mormente na modelação dos efeitos da declaração de inconstitucionalidade, reveste-se da natureza de regra jurídica. Os mecanismos por meio dos quais ele é tutelado na Constituição Federal não podem ser enumerados em rol exaustivo. Dentre eles, destacam-se, na dimensão objetiva, (i) a previsibilidade, (ii) o princípio da tipicidade tributária, (iii) o princípio da anterioridade, (iv) o princípio da irretroatividade, e (v) o tríduo do artigo $5^{\circ}$, do inciso XXXVI, da Carta Magna; e, na dimensão subjetiva, (vi) a proteção da confiança legítima e (vii) a proteção da boa-fé.

Quesito 2. A preservação dos atos praticados no passado por particulares e pela Administração Pública e das situações já consolidadas, com vistas à utilização do crédito-prêmio de IPI, realizada com lastro em decisões judiciais e em jurisprudência quinzenária mansa e pacífica, está garantida pelo princípio da segurança jurídica? Através de qual dos seus mecanismos ou institutos?

Resposta: Sim, concorrendo, de forma consistente, suficiente e eficaz, para sua tutela tanto os princípios da irretroatividade, anterioridade, tipicidade tributária, previsibilidade seja no prisma da correção funcional, seja na correção estrutural (dimensão objetiva), quanto os princípios da proteção da confiança legítima e da proteção da boa-fé (dimensão subjetiva).

Quesito 3. Neste contexto, qual é o papel que deve ser atribuído à Jurisprudência mansa e pacífica, que fundamentou a prolação de decisões judiciais favoráveis e a prática de atos de utilização do crédito-prêmio pelo particular, além dos correspondentes atos administrativos por parte da Secretaria da Receita Federal, em relação aos atos pretéritos praticados durante a sua vigência e às situações já consolidadas?

A \& C R. de Dir. Administrativo e Constitucional, Belo Horizonte, ano 5, n. 22, p. 183-236, out./dez. 2005 
Resposta: Conforme se expôs ao longo das considerações, a jurisprudência mansa e pacífica em relação ao crédito-prêmio de IPI viabilizou o efetivo respeito ao princípio da segurança jurídica, visto que conferiu não somente previsibilidade (notadamente por meio da correção funcional), calculabilidade, estabilidade, mensurabilidade (dimensão objetiva), mas também ensejou a emergência de confiança legítima e boa-fé (dimensão subjetiva) dos jurisdicionados em relação às decisões reiteradas, de modo que as empresas nelas pautaram-se na condução de suas atividades. Dimensões essas que, atreladas à total ausência de possibilidade dos particulares anteverem a guinada jurisprudencial, exigem, no caso em apreço, que eventual alteração de tal jurisprudência apenas opere efeitos prospectivos, isto é, apenas atinja as situações (exportações de produtos nacionais) que se realizarem após a sua plena divulgação e após a respectiva ciência efetiva dos particulares em relação à guinada.

Quesito 4. Eventual mudança de Jurisprudência poderá projetar efeitos para o passado, ocasionando a cobrança de valores decorrentes da utilização do crédito-prêmio de IPI?

Resposta: Não. Apenas, conforme já ressaltado na resposta ao quesito anterior, poderá projetar efeitos para o futuro.

Quesito 5. Com base na resposta ao quesito anterior, pode-se dizer que as situações já consolidadas ou os fatos consumados, ou seja, os atos de utilização do crédito-prêmio de IPI praticados pelo particular e pela Administração Pública, baseados em decisão judicial favorável e durante a vigência de jurisprudência mansa e pacífica devem ser preservados?

\section{Resposta: Sim.}

Quesito 6. Como pode ser definida a situação já consolidada ou o fato consumado à luz do princípio da segurança jurídica?

Resposta: São situações que, tendo em vista as peculiaridades do caso concreto do crédito-prêmio de IPI, merecem preservação haja vista a necessidade de tutelar, de proteger não somente a confiança legítima e a boa-fé dos particulares ensejadas pelas decisões reiteradas, pacíficas ao longo dos anos, mas também, de outra parte, 
de preservar a própria dignidade da atividade judicante, que, ao ser exercida, assegurou, na espécie, a observância do princípio constitucional da segurança jurídica. A preservação deve se dar não mediante o engessamento da jurisprudência, o que vulnera a dinamicidade inerente ao Direito, e sim por meio da aplicação de efeitos meramente prospectivos ao novo entendimento, vez que as decisões judiciais, ainda que não constituam fonte formal de direito, ensejam convicção de obrigatoriedade.

S.m.j.

É o parecer.

Curitiba, agosto de 2005.

Informação bibliográfica deste texto, conforme a NBR 6023:2002 da Associação Brasileira de Normas Técnicas (ABNT):

CLÈVE, Clèmerson Merlin. Parecer: crédito-prêmio de IPI e princípio constitucional da segurança jurídica. AE ${ }^{2}$ C Revista de Direito Administrativo e Constitucional, Belo Horizonte, ano 5, n. 22, p. 183-236, out./dez. 2005.

A \& C R. de Dir. Administrativo e Constitucional, Belo Horizonte, ano 5, n. 22, p. 183-236, out./dez. 2005 